\title{
Functional ultrastructure of the plant nucleolus
}

\author{
Dariusz Stẹpiński
}

Received: 18 September 2013 / Accepted: 8 April 2014 / Published online: 23 April 2014

(C) The Author(s) 2014. This article is published with open access at Springerlink.com

\begin{abstract}
Nucleoli are nuclear domains present in almost all eukaryotic cells. They not only specialize in the production of ribosomal subunits but also play roles in many fundamental cellular activities. Concerning ribosome biosynthesis, particular stages of this process, i.e., ribosomal DNA transcription, primary RNA transcript processing, and ribosome assembly proceed in precisely defined nucleolar subdomains. Although eukaryotic nucleoli are conservative in respect of their main function, clear morphological differences between these structures can be noticed between individual kingdoms. In most cases, a plant nucleolus shows well-ordered structure in which four main ultrastructural components can be distinguished: fibrillar centers, dense fibrillar component, granular component, and nucleolar vacuoles. Nucleolar chromatin is an additional crucial structural component of this organelle. Nucleolonema, although it is not always an unequivocally distinguished nucleolar domain, has often been described as a well-grounded morphological element, especially of plant nucleoli. The ratios and morphology of particular subcompartments of a nucleolus can change depending on its metabolic activity which in turn is correlated with the physiological state of a cell, cell type, cell cycle phase, as well as with environmental influence. Precise attribution of functions to particular nucleolar subregions in the process of ribosome biosynthesis is now possible using various approaches. The presented description of plant nucleolar morphology summarizes previous knowledge regarding the function of nucleoli as well as of their particular subdomains not only in the course of ribosome biosynthesis.
\end{abstract}

Handling Editor: Anne-Catherine Schmit

D. Stępiński $(\bowtie)$

Department of Cytophysiology, Faculty of Biology and

Environmental Protection, University of Łódź, Pomorska 141/143, 90-236 Łódź, Poland

e-mail: dareks@biol.uni.lodz.pl
Keywords Plant nucleolar ultrastructure · Nucleolar chromatin - Nucleolonema - Ribosome biosynthesis . Nucleolar functions · Nucleolar subcompartments

\section{Introduction}

Almost to the end of the twentieth century, the nucleolus was recognized only as a factory producing ribosomes that is maintained by them (Mélèse and Xue 1995). Thus, it was thought that nucleolar dynamics was associated solely with storage and traffic of numerous proteins and ribonucleoproteins involved in ribosome particle biosynthesis and transport. Moreover, due to mutual integration of these processes, three nucleolar compartments were recognized, i.e., fibrillar centers (FCs), dense fibrillar component (DFC), and granular component (GC; Goessens 1984; Shaw and Jordan 1995).

However, in the past two decades, when new approaches were employed to investigate nucleoli, our conception of nucleolar functioning both with respect to ribosome biogenesis (Sáez-Vásquez and Medina 2008) and to other activities was rebuilt. Nucleolar proteomics showed that nucleoli are far richer in proteins and protein-containing complexes (Andersen et al. 2002; Pendle et al. 2005; Ahmad et al. 2009) than it was previously thought. Since then, it has turned out that nucleoli are multifunctional nuclear domains playing noncanonical roles in many crucial cellular processes such as for example: response to stress or viral infections, control of aging, sequestration of regulatory molecules, modification of different types of RNA, RNP assembly, as well as nuclear export (Guarente 1997; Pederson 1998, 2010; Olson et al. 2002; Boisvert et al. 2007; Sirri et al. 2008; Kim 2009; Shaw and Brown 2012). Some of these functions use the same conventional nucleolar compartments as ribosome biosynthesis does. Nevertheless, maintenance of the local concentration of specific macromolecules at various sites of nucleolar 
territory pointed out to these sites as additional nucleolar domains playing defined functions (Costanzo et al. 2011; Hutten et al. 2011; Latonen et al. 2011).

The current review presents the morphological character of particular nucleolar subcompartments and the roles that they play at successive stages of ribosome biosynthesis. Moreover, attempts were made to match some new nucleolar functions with already known subcompartments as well as other nucleolar activities with newly observed nucleolar subdomains.

Although the plant nucleoli are the main interest of the article, plenty of new functions as well as additional nucleolar subregions not concerning plants, were also taken into account because of their significance and novelty. However, they are presented mostly in tables in order to demonstrate the similarities and differences between the two systems more clearly.

\section{A nucleolus as a nuclear domain}

Nucleolar position in nucleus

Nucleoli are the largest bodies in eukaryotic interphase cell nuclei. Since, the position of all chromosomes in a nucleus is determined by the precise anchoring of chromatin domains in lamin lying just below the nuclear envelope (HernandezVerdun 1991; Cremer et al. 2006), also the position of nucleoli in nuclei is not random as it is conditioned by the location of nucleolus-forming chromosomes, exactly by the position of nucleolus organizer regions (NORs; Fernandez-Donoso et al. 1979; Kalmárová et al. 2007). Moreover, a cytoskeleton was also attributed a role in determining the nucleolar position in a nucleus (Sameshima et al. 1991). The nucleolar position remains stable from telophase through interphase to prophase, and what is more, it is maintained in daughter cells (Kalmárová et al. 2007).

\section{After-cell cycle nucleolar restoration}

After each cell division nucleoli are rebuilt on the basis of those portions of NORs that contain ribosomal genes ( $r$ genes), which were transcriptionally active in the previous interphase and during mitosis they remain relatively decondensed to form the secondary constrictions on metaphase chromosomes; the inactive r-genes are included in the nonforming nucleolus NORs (Heliot et al. 1997; Mais et al. 2005; Prieto and McStay 2008) (additional information is included in "Nucleolar chromatin"). Moreover, newly formed nucleoli are restored from r-gene products, i.e., primary ribosomal transcripts (pre-ribosomal RNAs (rRNAs)) being at various stages of processing as well as components of transcriptional and processing machineries including such factors as U3 snoRNA, fibrillarin, nucleolin, B23, and Nop52, which are transmitted from previous interphase nucleoli to the new ones first in the form of perichromosomal compartments and then prenucleolar bodies (PNBs) and nucleolus-derived foci (NDF; Dundr and Olson 1998; Hernandez-Verdun 2011; Carron et al. 2012). The number of NOR-bearing chromosomes vary from species to species, hence at the end of mitosis, late telophase, each part of active NOR is responsible for the formation of one or more nucleoli, depending on species. At this time, the nucleoli undergo fusion, especially it is characteristic of plants, hence, the number of nucleoli is usually smaller than of active NORs in a genome (Jordan et al. 1982).

\section{A nucleolus, a ribosome biofactory}

The nucleoli are specialized nuclear compartments in which many processes associated mainly with ribosome production occur (Cmarko et al. 2008). At the nucleolar territory, RNA polymerase I mediates the transcription of the pre-rRNA, in the form of $45 \mathrm{~S}$ rRNA, from which three of four rRNA species, $18 \mathrm{~S}, 5.8 \mathrm{~S}$, and $28 \mathrm{~S}$ rRNAs are formed in the course of pre-rRNA maturation (Nazar 2004; Russell and Zomerdijk 2005). In higher eukaryotes at the extranucleolar nucleoplasm territory, the fourth rRNA species, 5S rRNA, is transcribed from tandemly arrayed repeats located out of NORs by means of RNA polymerase III; then, it is transported to the nucleolus (Highett et al. 1993a). After processing, appropriate rRNA species together with ribosomal proteins are assembled into small and large ribosomal subunits (Fromont-Racine et al. 2003).

\section{Control of ribosome production yield}

In actively growing and metabolizing cells, the largest part of total RNA synthesis falls into ribosomal DNA (rDNA) transcription, 40-80\% (Warner 1999), hence nucleoli play an essential role in cell growth regulation (Lempiäinen and Shore 2009). The need for ribosome production and its rate are correlated with the cell demand for protein biosynthesis and are highly influenced by the cell status, lower in differentiated cells with reduced protein biosynthesis, and higher-in proliferating, growing cells (Warner 1999; Medina et al. 2000; Rudra and Warner 2004). Productivity of ribosome manufacturing is correlated with the following parameters: (1) the number of active r-genes which is controlled by epigenetic mechanisms switching on or off the transcriptionally competent chromatin, (2) the rate of rDNA transcription, prerRNA processing, and ribosome assembly, (3) the number of factors available for these processes such as RNA polymerase I complexes, early and late processing, and ribosomal proteins as well as snRNAs and snoRNAs (Brown and Shaw 1998; Grummt and Pikaard 2003; Preuss and Pikaard 2007; Strunk and Karbstein 2009). 
rDNA transcription regulators

In eukaryotic cells, the ribosome biosynthesis is a complex process which may be controlled at many levels. Transcription initiation seems to be the key stage that determines success of the whole process, hence it is the best characterized step in RNA polymerase I transcription at least in animals (Grummt 2003). Before rDNA transcription starts, the formation of preinitiation complex (PIC) is required on the promoter sequence of r-gene. In animals, this complex consists of two main elements, an upstream binding factor (UBF) and a selectivity factor (SL1). RNA polymerase I recruitment by PIC is mediated by another key player, a transcription initiation factor (TIF-IA; Yuan et al. 2002). The control of elongation stage during rDNA transcription is also important for the overall rRNA synthesis rate as well as for efficient pre-rRNA processing (Schneider et al. 2007). The issue of RNA polymerase I action and main factors participating in this process was the focus of the recent review (Schneider 2012).

Concerning plants, little is known about transcription factors constituting of the rRNA transcriptional machinery and it cannot be excluded that this machinery may be regulated similarly as in animals. It is obvious that RNA polymerase I holoenzyme complex, which is associated with its several protein subunits, acts at plant rDNA promoters (Sáez-Vásquez and Echeverría 2006). Moreover, it is also possible that functional homologs of UBF might exist in plants as UBF-like proteins were identified in onion nucleoli by means of antibodies recognizing animal UBF (Rodrigo et al. 1992; De Cárcer and Medina 1999; Tao et al. 2001). However, an unequivocal role of these proteins in rDNA transcription has not been demonstrated yet. It is possible that different systems, including plants, have their own, specific key transcriptional regulators.

The regulation of r-gene transcription is tightly connected with ribosomal chromatin (r-chromatin; chromatin-containing rDNA/r-genes/rRNA genes) structure. The chromatin competence may be controlled by many factors (see "Nucleolar chromatin").

\section{Nucleolar compartmentation}

The nucleoli are an example of model cellular organelles whose compartmentational organization correlates with precisely defined functions associated with ribosome biosynthesis. The confinement of specific protein and ribonucleoprotein machineries to different nucleolar territories imposes on the compartments the sites where successive steps of ribosome biogenesis are realized. Dynamic integration of rDNA transcription, pre-rRNA processing, and assembly of ribosomal subunits generates typical nucleolar organization. Although in general these events are highly organized and distinct spatially and temporally in the plant nucleoli (Shaw et al. 1995; Shaw 2005), rDNA transcription and pre-rRNA processing might be functionally coupled to each other in yeast (Schneider et al. 2007). It has been proposed that transient association of functionally related components is involved in generation of morphologically defined nucleolus with its main distinct compartments (Hernandez-Verdun 2006). This would concern nucleoli in proliferating cells passing through cell cycles. In the case of differentiated cells, where nucleoli are present all the time, the permanent but not transient interactions between nucleolar components are supposed to occur. The interactions may obviously be provided by continuous rDNA transcription, pre-rRNA processing, and ribosome assembly. The other question arises whether the same forces and mechanisms act in both cell types to keep the compartments integrated.

The structural model of plant nucleoli was mainly based on electron microscopic examinations using different techniques of revealing particular nucleolar territories (Figs. 1a, b, 2a, and 3b) (Trendelenburg et al. 1996). Cytochemical investigations supplemented ultrastructural and morphological studies. Research in recent decades allowed for the precise analysis of particular nucleolar subcompartments and assigned to them appropriate functions during ribosome biosynthesis (Beven et al. 1996). The nucleolar subdomains form a radial pattern in which newly synthesized pre-ribosomal transcripts move away from the FC-DFC border towards the periphery of nucleoli through DFC and GC (Brown and Shaw 1998).

The organization and structure of the nucleolus may vary according to the cell type, cell cycle, physiological state of the cell, transcriptional activity of the nucleolus, impact of biotic and abiotic factors, and to a certain extent according to species (Risueño and Medina 1986; Derenzini et al. 2000; Medina et al. 2000; Hernandez-Verdun et al. 2002; Stępiński 2009). Moreover, diversity of nucleolar architecture is striking especially when animal and plant nucleoli are compared. At the ultrastructural level, the plant nucleolus, which is generally regular in the higher plant kingdom, is often nearly spherical in shape and consists of four main readily distinguishable regions (Fig. 1a, b). The arrangement of these nucleolar subregions, including their proportion and distribution pattern, can change depending on the abovementioned reasons (González-Camacho and Medina 2006). Soybean is an attractive material for studying nucleoli due to the fact that the soybean cell nucleus possesses one big nucleolus with its all main subcompartments. These nucleolar subdomains include: FCs, DFC, GC, nucleolar vacuoles (NoV) (Fig. 1a, b). Nucleolonema and nucleolar chromatin are additional components distinguished in nucleoli (Figs. 2a and 3b). All images which are included in this review represent the soybean nucleoli and come from the author's own examinations. 

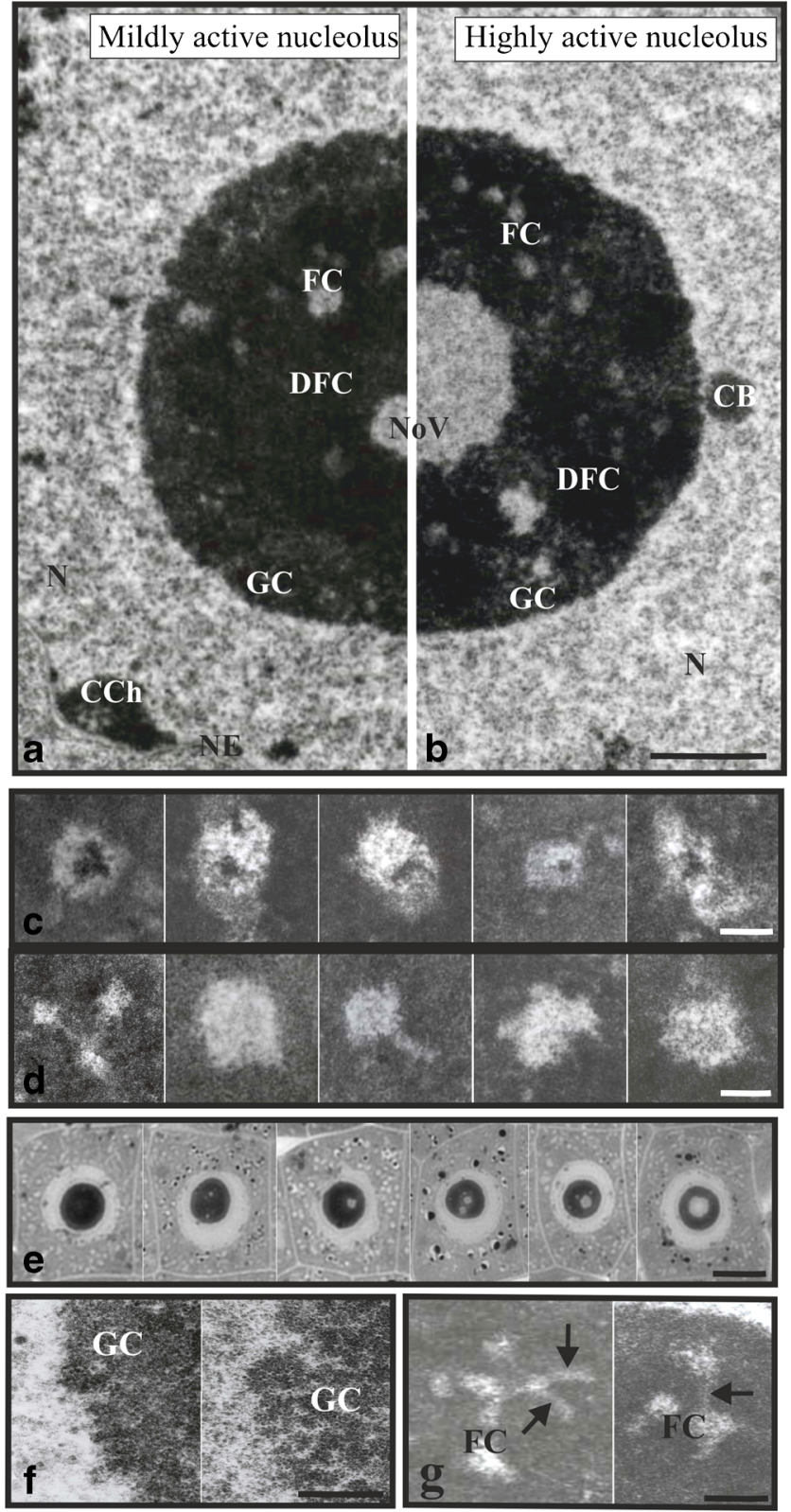

Fig. 1 Typical plant nucleoli of tip root meristem cells and nucleolar components. Ultrastructure of nucleoli, representing four-component morphology, i.e., fibrillar centres $(F C)$, dense fibrillar component $(D F C)$, granular component $(G C)$, and nucleolar vacuoles $(\mathrm{NoV})$; conventional electron microscopy technique images $(\mathbf{a}, \mathbf{b})$. A nucleolus with mild transcriptional activity; it is characterized by lower number of FCs and small NoV (a). A nucleolus with high transcriptional activity with greater number of FCs and big, centrally located NoV (b). Scale bar, $2 \mu \mathrm{m}$. Examples of different size and shape FCs $(\mathbf{c}, \mathbf{d})$ : heterogeneous FCs containing clumps of condensed chromatin (c). Scale bar is $0.5 \mu \mathrm{m}$. Homogenous FCs (d). Scale bar, $0.5 \mu \mathrm{m}$. Tip root meristematic cells with nucleoli in which $\mathrm{NoV}$ are formed, from small $\mathrm{NoV}$ in nucleoli with low transcriptional activity, through bigger and bigger vacuoles in nucleoli with higher and higher activity, up to one big, centrally located vacuole in nucleoli with high transcriptional activity; semi-thin sections (e). Scale bar, $10 \mu \mathrm{m}$. GC of a regular nucleolus (left) and loosened GC of a low transcriptionally active nucleolus of the chilled soybean seedling (right) (f). Scale bar, $0.5 \mu \mathrm{m}$. Examples of FCs connecting with each other by canals (arrows) running through dense fibrillar component (g). Scale bar, $1 \mu \mathrm{m} . N$ nucleus, $C C h$ condensed chromatin, $C B$ coiled body, $N E$ nuclear envelope
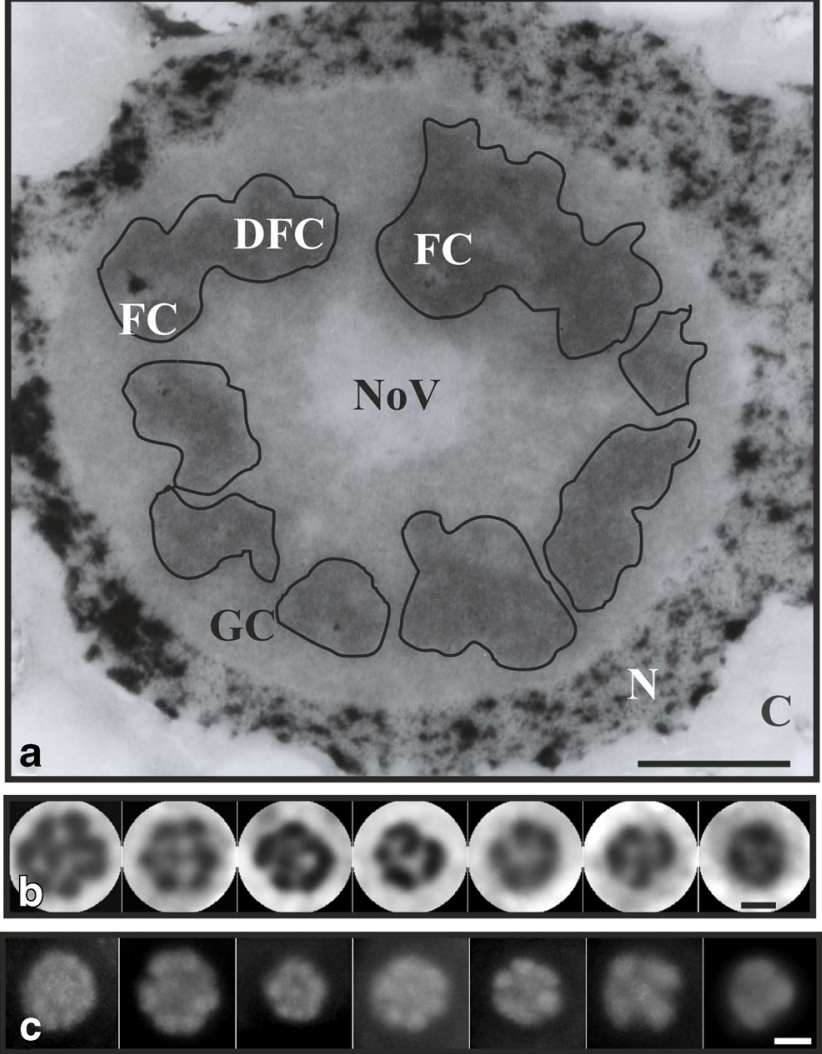

Fig. 2 Plant nucleolonema. Ultrastructure of a plant nucleolus with clearly visualized nucleolonema (dark nucleolar areas encircled with lines); modified NAMA-Ur technique (a). Scale bar, $2 \mu \mathrm{m}$. Nucleoli impregnated with silver nitrate; circular-shaped areas as nucleolonema units; the number and sizes of the units are correlated with nucleolar transcriptional activity, the greater number and bigger units, the more active nucleolus (b). Scale bar, $5 \mu \mathrm{m}$. Immunofluorescent identification of fibrillarin, one of the key nucleolar protein and main protein component of nucleolonema as well as a marker of dense fibrillar component; circular areas correspond to those obtained with silver impregnation, their number and sizes also correspond to nucleolar activity (c). Scale bar, $5 \mu \mathrm{m}$. $F C$ fibrillar centre, $D F C$ dense fibrillar component, $G C$ granular component, $\mathrm{NoV}$ nucleolar vacuole, $N$ nucleus, $C$ cytoplasm

\section{Fibrillar centers}

These subcompartments are visible in electron microscope as lightly stained nucleolar areas different in size and shape, completely immersed in DFC in plants (Fig. 1a-d, g; Table 2). It is interesting that there are species, within chordates, showing bipartite nucleolar organization with no FCs at all (Thiry et al. 2011).

In plant meristematic cell nucleoli, two types of FCs have been distinguished, heterogeneous and homogenous ones (Table 1). The former contains both condensed and loosened r-chromatin (Fig. 1c), while the latter contains solely loosened rDNA (Fig. 1d) (Risueño et al. 1982). The FC loosened nonnucleosomal chromatin, although structurally indistinguishable, may be present in two states: transcriptionally active or silent (Derenzini et al. 2006). A given type of FC that occurs 
Fig. 3 Nucleolar chromatin. DAPI staining DNA; an interphase nucleus with condensed chromatin segments visualized as fluorescent bright spot chromocentres, while nucleolus remained as not stained circular area; arrows point to nucleolus-associated chromatin (NAC); mitotic chromosomes at position of metaphase and anaphase (a). Scale bar, $10 \mu \mathrm{m}$. A nucleolus with visualized NAMA-Ur technique staining chromatin, including two clumps of NAC, FC-condensed chromatin $(F C)$, and nucleoplasmiccondensed chromatin $(\mathrm{CCh}) ; \mathrm{N}$ nucleus, $\mathrm{No}$ nucleolus, $\mathrm{No} \mathrm{V}$ nucleolar vacuole (b). Scale bar, $2 \mu \mathrm{m}$. Examples of NAC-entering No through channel-like structures and localizes to FC (c). Scale bar, $1 \mu \mathrm{m}$. Chromatin strand (arrow) connecting two condensed chromatin clumps, disclosed by NAMA-Ur method, located to two different FC (d). Scale bar, $0.5 \mu \mathrm{m}$
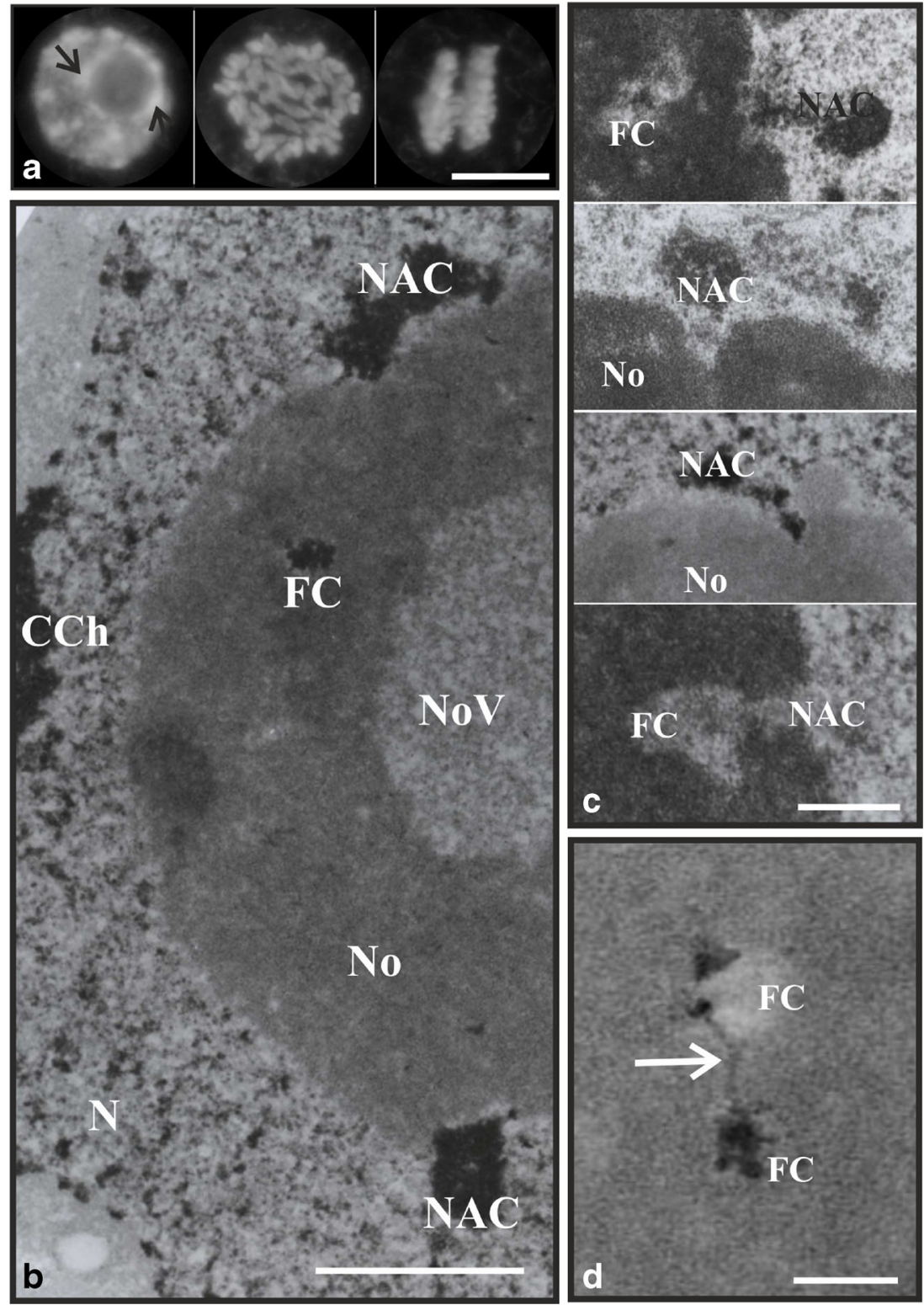

Table 1 Characteristics of the plant homogenous and heterogeneous fibrillar centres (FCs)

\begin{tabular}{|c|c|c|}
\hline \multirow[t]{2}{*}{ Parameter } & \multicolumn{2}{|l|}{ FC interior } \\
\hline & Homogenous & Heterogeneous \\
\hline Activity status of nucleolus & High activity (Bassy et al. 2000) & Low activity or in the process of activation (Bassy et al. 2000) \\
\hline Size & Small (Thompson et al. 1997) & Large (Thompson et al. 1997) \\
\hline Number & Numerous (Sobol et al. 2005) & Few (Sobol et al. 2005) \\
\hline \multicolumn{3}{|l|}{ Composition } \\
\hline DNA/rDNA chromatin & Loosened chromatin (Risueño et al. 1982) & Both loosened and condensed chromatin (Risueño et al. 1982) \\
\hline RNP fibrils/rRNA & Absent (Bassy et al. 2000) & Present (Bassy et al. 2000) \\
\hline Processing elements/ snoU3RNA & Absent (Bassy et al. 2000) & In the process of activation (Bassy et al. 2000) \\
\hline Silver staining & Argyrophilic (Medina et al. 1983b) & Non-argyrophilic (Medina et al. 1983b) \\
\hline
\end{tabular}


in plant nucleolus depends on species (Sato and Myoraku 1994; Stępiński 2010). It is also believed that appearance of either type of FCs depends on the nucleolar transcriptional activity, heterogeneous FCs are characteristic of nucleoli with reduced activity or of dormant cells, while homogenous FCs - of actively transcribing nucleoli (Risueño et al. 1982). However, FCs undergo morphological changes and may transform into each other according to nucleolar activity (Medina et al. 1983a; Highett et al. 1993b). Moreover, nucleolar activity influences the FC sizes, the transcriptionally active nucleoli usually possess many small FCs, while large FCs are characteristic of inactive or low-activity nucleoli (Risueño et al. 1982; Thompson et al. 1997; Sobol et al. 2005). However, this is not a general rule, it also depends on species, for instance the soybean nucleoli both those with high and low transcriptional activity, i.e., under optimal or chill growth conditions respectively, possess individual FCs of the same average sizes but their number differs, it is greater or lower, respectively (Stępiński 2010). The number and sizes of FCs are also correlated with phases of the cell cycle, cells in $\mathrm{G}_{1}$ phase usually possess lower number of FCs, about half, than those in $\mathrm{G}_{2}$ phase (Grummt 2003; González-Camacho and Medina 2006). Heterogeneous FCs are also present in active nucleoli entering mitosis at late prophase as well as exiting from mitosis at telophase (Moreno Díaz de la Espina et al. 1976).

Plant FCs are the sites of the assembly of both complexes containing transcription-associated factors in inactive state and those ready for transcription (De Cárcer and Medina 1999). They are also the site of location of "potentiated" rDNA, not engaged in transcription at the moment but available for this process (Shaw et al. 1996; McKeown and Shaw 2009), moreover, the activation of r-chromatin for transcription takes place in them (Martin and Medina 1991; De Cárcer and Medina 1999). Although r-genes and the components of RNA polymerase I transcriptional machinery have been localized to FCs, the rDNA transcription products have never been localized inside homogenous FCs of active nucleoli; probably neither type of FCs contains rRNA. However, the early transcripts are localized inside the onion heterogeneous FCs of quiescent cell nucleoli in the process of their activation (Bassy et al. 2000). These FCs contain U3 and RNP fibrils which means that also maturation of pre-rRNA could take place in them or at least they could be the sites of sequestration of the processing machinery components (Bassy et al. 2000).

It cannot be excluded that FCs could be the site in which transcription of pre-rRNA occurs in specific circumstances, e.g., in dormant cells entering activation. Such a situation occurs when onion quiescent meristematic cells develop into active ones, then large heterogeneous FCs fragment into smaller ones, and simultaneously clusters of condensed chromatin become loosened in them (Bassy et al. 2000). Generally, central parts of FCs are believed not to be the site of rDNA transcription even if there is r-chromatin in the form of inactive r-genes or ready to be transcribed. Only at the peripheral parts of FCs the transcription of rDNA could proceed (Staněk et al. 2001).

FCs were often interpreted as interphasic counterparts of mitotic NORs. It is not precise because only part of the NORs that are temporarily transcriptionally inactive could form FCs, the rest, active NORs together with nascent transcripts, generate the DFC. It means that when in cells all ribosomal genes are engaged in transcription their nucleoli would be devoid of FCs (Risueño et al. 1982). Conversely, dormant or quiescent cell nucleoli have large heterogeneous FCs, and this is the case where the number of FCs correspond with the number of NORs (Martin et al. 1989).

Despite the fact that FCs participate in the abovementioned processes, this subcompartment seems to be faintly used even in relation to ribosome biosynthesis. From ultrastructural point of view, electron clear FCs, similarly as NoV, appear to be areas convenient for temporal sequestration and accumulation of various components (Table 2).

It is obvious that plant and animal FCs are not identical and may differ to some extent both in terms of composition and function (Table 2). While the presence of RNA polymerase I was clearly evidenced in animal FCs (Scheer and Rose 1984; Prieto and McStay 2005), in plants it is a matter of controversy. However, in onion nucleolar homogenous and heterogeneous FCs this enzyme was identified indirectly as nucleolar RNA polymerase by means of an antibody raised against RNA polymerase II from Drosophila (Martin and Medina 1991). The authors even suggested that initial steps of r-gene transcription took place in them. There is also a controversy concerning the presence of argyrophilic proteins. These proteins, including nucleolin, were identified in FCs of some animals (Ploton et al. 1987; Hozák et al. 1992), however, in other animals, nucleolin was not observed although silverstained proteins were localized in FCs (Lamaye et al. 2011). With respect to plants, although there are prevailing contentions that AgNOR proteins are absent from these nucleolar regions (Motte et al. 1988b; Moreno et al. 1989a, 1989b, 1990; Wei et al. 2003), some studies revealed silver grains in FCs of plants at the ultrastructural level after silver impregnation (Medina et al. 1983b, 1986). Moreover, several nucleolin homologs or nucleolin-like proteins were identified in plants and localized in FCs with the use of electron microscopy immunogold technique. The antibody raised against animal nucleolin showed the presence of the protein in FCs of onion meristem cell nucleoli (Martin et al. 1992) and in the peripheral part of FCs in isolated onion nucleolar matrix (Minguez and Moreno Diaz de la Espina 1996). Furthermore, the antibodies raised against onion nucleolin homolog, NopA100 or NopA64, recognized the protein in FCs of cress nucleoli (Sobol et al. 2005, 2006), while in onion out of FCs (González-Camacho and Medina 2004; Medina et al. 2010). 
Table 2 Comparison of the fibrillar centres (FCs) in plant and animal nucleoli

\begin{tabular}{|c|c|c|}
\hline \multirow[t]{2}{*}{ Parameter } & \multicolumn{2}{|l|}{ FCs in } \\
\hline & Plants & Animals \\
\hline Type & Heterogeneous and homogenous (Risueño et al. 1982) & $\begin{array}{l}\text { Fibrous, uniform texture similar to plant homogenous } \\
\text { FC (Thiry et al. 1993) }\end{array}$ \\
\hline Size & $\begin{array}{l}0.1-0.7 \mu \mathrm{m} \text { (onion) (De Cárcer and Medina 1999) } \\
0.2-1.0 \mu \mathrm{m} \text { (pea) (Nougarede et al. 1990), and } \\
0.22-0.58 \mu \mathrm{m} \text { (maize and mustard) (Deltour and } \\
\text { Mosen 1987) - in diameter }\end{array}$ & $\begin{array}{l}\text { Different sizes, generally larger than in plants } \\
\text { (Derenzini et al. 2006), 0.51-4.56 } \mathrm{\mu m}^{3} \times 10^{-2} \\
\text { (Jordan and McGovern 1981);1-2 } \mu \mathrm{m} \text { (in diameter; } \\
\text { giant fibrillar centre (GFC)) (Casafont et al. 2007) }\end{array}$ \\
\hline Number per nucleolus & $\begin{array}{l}\text { Numerous; e.g. } 38 \text { (mean number of FCs in anion active } \\
\text { nucleolus) (Medina et al. 1983b) }\end{array}$ & $\begin{array}{l}\text { One to several tens, (Derenzini et al. 2006) even more } \\
\quad(42-234) \text { (Jordan and McGovern 1981) }\end{array}$ \\
\hline Shape & Various (Stępiński 2013) & Usually spherical (Derenzini et al. 2006) \\
\hline Volume occupied in nucleolus & $2 \%$ (Shaw et al. 1996) & $1 \%$ (Shaw et al. 1996) \\
\hline \multicolumn{3}{|l|}{ Composition } \\
\hline DNA/rDNA & $\begin{array}{l}\text { Non-nucleosomal loosened and nucleosomal- } \\
\text { condensed chromatin (Medina et al. 2000); } \\
\text { "potentiated" rDNA (McKeown and Shaw 2009) }\end{array}$ & $\begin{array}{l}\text { Nucleosomal and non-nucleosomal extended } \\
\text { chromatin (Derenzini et al. 2006); poised r-genes } \\
\text { (Németh and Längst 2011) }\end{array}$ \\
\hline RNA pol I & $\begin{array}{l}\text { In heterogeneous FCs during activation } \\
\text { (Martin and Medina 1991) }\end{array}$ & $\begin{array}{l}\text { Transcribing (Raška et al. 1989; Scheer and Rose } \\
\text { 1984; Thiry and Lafontaine 2005) and nontranscribing } \\
\text { (Raška 2003) molecules of RNA pol I }\end{array}$ \\
\hline Argyrophilic proteins & Controversial matter (see in text) & Present (Thiry and Lafontaine 2005) \\
\hline Pontin protein & Not determined & $\begin{array}{l}\text { Colocalizes with ubiquitin-proteasome system and } \\
\text { RNA polymerase I (Cvačková et al. 2008) }\end{array}$ \\
\hline Tumor suppressor p53 & Not determined & $\begin{array}{l}\text { ATP-dependent accumulation after proteasome activity } \\
\text { inhibition (Karni-Schmidt et al. 2008) }\end{array}$ \\
\hline rDNA transcription & Initiation of transcription (Martin and Medina 1991) & Occurs (Huang 2002; Cheutin et al. 2002) \\
\hline Presumable function & $\begin{array}{l}\text { Accumulation of inactive rDNA (Shaw et al. 1996) } \\
\text { and assembly of r-gene transcription machinery } \\
\text { (Medina et al. 2000) }\end{array}$ & $\begin{array}{l}\text { rDNA transcription initiation (Cheutin et al. 2002); } \\
\text { accumulation of components of RNA pol I transcription } \\
\text { machinery (Prieto and McStay 2005) }\end{array}$ \\
\hline $\begin{array}{l}\text { Counterparts of mitotic } \\
\text { NORs }\end{array}$ & $\begin{array}{l}\text { Equivalent structures in dormant nucleoli, } \\
\text { partially in others (Medina et al. 1983b) }\end{array}$ & $\begin{array}{l}\text { Partial equivalent structures in mammalian nucleoli } \\
\text { (Derenzini et al. 2006) }\end{array}$ \\
\hline $\begin{array}{l}\text { Participation in } \\
\text { nucleolonema formation }\end{array}$ & Participate (Deltour and Motte 1990) & Do not participate (Deltour and Motte 1990) \\
\hline Relationship to DFC & $\begin{array}{l}\text { Completely embedded in large masses of DFC } \\
\text { (Thiry et al. 2011) }\end{array}$ & $\begin{array}{l}\text { Completely or partially surrounded by DFC thin layer } \\
\text { (Thiry et al. 2011) }\end{array}$ \\
\hline
\end{tabular}

To find out the analogy between protein components in plant and animal FCs, a precise comparison of the amino acid sequences, antigenic epitopes, and functions of the given proteins is necessary. In addition, different results can be obtained analyzing the same parameter, depending on species, technique, its precision, biochemical reagents, interpretation, etc. Moreover, the presence of a nuclear protein in any nucleolar region is not a surprise because of simple diffusion. However, it does not mean that this protein functions there but it may be solely detectable during a limited time. The retention time of a protein within various nucleolar subcompartments is determined by its own activity and affinity to local factors.

Regardless of the differences mentioned in this section, the plant counterparts of animal FCs are termed FCs in literature according to nucleolar nomenclature (Jordan 1984), although some researchers do not share this idea.

\section{Dense fibrillar component}

This nucleolar domain, because of its density, is often the darkest nucleolar territory (Fig. 1a, b), however, nucleolar chromatin can be darker. DFC consists of rather short fibers of different lengths which are products of currently transcribed r-genes, as DFC is the site of pre-rRNA transcript elongation and of temporal residence of transcripts at different intermediate stages of processing (Shaw et al. 1998).

In the plant nucleoli, DFC occupies the majority of nucleolar territory (from $40 \%$ to more than $70 \%$ ) (Figs. 1a, b and 2a) (Shaw and Jordan 1995; Stepiński 2010) and corresponds to the nucleolonema matrix, see below (Yano and Sato 2000), while in animals this region constitutes solely a thin layer, perhaps because of a lower number of active r-gene units. From morphological and ultrastructural point of view, this whole region seems to be homogenous and structurally 
indistinguishable. However, with regards to pre-rRNA processing events, it is divided into subtle subcompartments in which particular steps of pre-rRNA maturation occur, as different intermediates of processing, i.e., rRNA transcripts at different stages of maturation, occupy various subdomains of DFC (Lazdins et al. 1997; De Cárcer and Medina 1999).

At DFC territory mainly the early steps of pre-rRNA processing and modifications occur. However, successive stages of the processing also take place in DFC as the distance from FC-DFC border increases, according to the vectorial model from inside out (Shaw et al. 1995; Brown and Shaw 1998). However, this functional-morphological pattern was extended, in addition to radial functional differentiation of DFC also lateral variability was distinguished (De Cárcer and Medina 1999).

Fibrillarin, one of the crucial nucleolar proteins, participates in pre-rRNA maturation. It is a component of Box C/D snoRNAs included in the terminal balls of nascent rRNA transcript at 5'ends (Mougey et al. 1993; Fatica et al. 2000; Gerbi et al. 2003). Thus, this protein acts directly in 2'-Oribose methylation of pre-rRNA (Barneche et al. 2000; Dunbar et al. 2000), and it is probably part of the complex participating in its early cleavages and ribosome assembly (Henriquez et al. 1990; Sáez-Vásquez et al. 2004). Fibrillarin is a highly conserved multifunctional protein which is not only essential for ribosome production but it is additionally implicated in early stages of mouse embryo development (Newton et al. 2003), yeast cell viability (Schimmang et al. 1989), as well as in HeLa cell growth and proliferation (Amin et al. 2007). Despite fibrillarin involvement in nucleolar functions, depletion of the protein does not influence the nucleolar structure, but interestingly it affects nuclear morphology, suggesting its role also in nuclear functions (Amin et al. 2007). Its retention is mainly limited to the nucleoli, which is related to active rRNA transcription, however its subcellular distribution depends on the cell type, cell cycle phase and treatments (Chen and Jiang 2004). Fibrillarin abundantly resides in DFC that is why it is considered to be DFC marker, although it has also been found to localize in FCs (Ochs et al. 1985). Thus, in fluorescence microscope, after the use of the antibody recognizing fibrillarin, almost whole plant nucleoli are decorated with the separated circular domains (Fig. 2c) similar to those when nucleoli are impregnated with silver nitrate (Fig. 2b). It is suggested that these domains are nucleolar units active in ribosome production, mainly in primary transcript maturation. Their number and sizes are correlated with transcriptional activity of the nucleoli, the more numerous and bigger these domains the more transcriptionally active nucleoli (Stępiński 2009).

FCs together with DFC are structurally and functionally associated with nucleolonema (Fig. 2a). This additional nucleolar component, although not always unequivocally described and discriminated, has already received the status of the fundamental nucleolar structure. Nucleolonema is built of a threadlike component which prevails in nucleoli and is generally characteristic of higher plants. In the animal nucleoli, this structure is often difficult to distinguish probably because of small content of DFC, however, nucleolonema is clearly visible in the animal reticulate nucleoli (Deltour and Motte 1990).

From morphological point of view, nucleolonema consists of a tandem array of structural units. Each of these units forms a radial complex of main nucleolar components, i.e., FCcondensed chromatin, peripheral part of FC with lightfibrous material, containing probably nucleolar proteins intermingled with chromatin threads, FC itself, FC-DFC border as well as DFC (Fig. 2a, b) (Yano and Sato 2000; Sato et al. 2005). The ducts, connecting the centers (FCs) of particular nucleolonema units (Fig. 1g), in which nucleolar chromatin runs (Fig. 3d), pass across the whole nucleolonema.

In plants, the matrix of nucleolonema can be readily recognized in light microscope after glutaraldehyde fixation followed by impregnation of nucleoli with silver nitrate, as spherical or knob-like domains arranged into nucleolar wreath with one or more argyro clear holes corresponding to FCs in each of such domains (Fig. 2b) (Sato and Fujie 1997). Nucleolonema, after modified sodium hydroxide methylation-acetylation plus uranyl acetate (NAMA-Ur) technique and double-contrasting with lead citrate and uranyl acetate, can be also easily distinguished in transmission electron microscope as electron dense nucleolar area with light FCs embedded in DFC (Fig. 2a). It is especially well visible in the nucleoli with decreased transcriptional activities due to low temperature treatment of soybean seedlings. These nucleoli show noncompact structure, mainly loosened GC (Fig. 1f) (Stępiński and Kwiatkowska 2003; Stępiński 2009). Generally, nucleolonema easily responds to any disturbances resulting in inhibition of rDNA transcription which is manifested by segregation of nucleolonema with simultaneous changes of FC shapes (Sato et al. 2005).

The regions forming nucleolonema, $\mathrm{FC}$, and $\mathrm{DFC}$, are important nucleolar subcompartments in which the key stages of ribosome biogenesis, pre-rRNA synthesis, and main steps of processing, take place. In spite of the studies conducted for many years with different experimental approaches and systems, the exact site of rDNA transcription still remains under debate. In order to localize rDNA transcription and particular stages of pre-rRNA processing in situ, a lot of experimental techniques have been employed. Autoradiography with the use of ${ }^{3} \mathrm{H}$-uridine marks the sites of incorporation of this transcription precursor (Goessens and Lepoint 1979). This technique is insufficiently precise unless an electron microscope is used instead of a light microscope (Wachtler et al. 1990). Immunogold electron microscopy studies with the use of bromo-uridine (BrUTP), which is introduced into transcripts by all types of RNA polymerases, localizes 
transcription sites more precisely (Dundr and Raska 1993; Thompson et al. 1997). Initial stages of pre-rRNA processing can be localized by means of fluorescence in situ hybridization (FISH) method which exploits probes that are complementary, for example, to $5^{\prime}$ external transcribed spacer (ETS), a fragment of pre-rRNA which is removed at the early stage of pre-rRNA maturation (Lazdins et al. 1997). No matter which precise method and which systems are used, the results might be quite different, as the nucleoli and their subcompartments are only seemingly stable domains.

The results obtained with the above mentioned methods have shown that in plants the FC periphery, the border between FC and DFC, and DFC adjacent to FCs are most probably the key structural areas where active r-genes are located and where the rDNA transcription occurs, or at least where the transcription starts and the earliest stages of processing proceed. However, not the whole region but only focal transcriptional domains take part in this process (De Cárcer and Medina 1999; Yano and Sato 2000; Huang 2002). In plants, r-gene units with nascent pre-rRNA transcripts can be visualized in the form of condensed Christmas trees localized at these sites of transcription (González-Melendi et al. 2001; Raška 2003). In animals, the transcription zone is additionally shifted to more distant region of DFC, but it does not exceed this region (Staněk et al. 2001) and transcriptional units appear in the same form of Christmas trees (Koberna et al. 2002).

Another question arises whether rRNA transcription and early stages of pre-rRNA processing proceed separately or simultaneously. The matter has not yet been elucidated unequivocally for individual systems, even among various plant species, and it is supposed to differ. In plants, there are nucleolar domains in which solely rDNA transcription without processing was localized. However, there are also regions where both transcription and early steps of processing were found to overlap judging from the colocalization of marker proteins engaged in these processes, the RNA polymerase I transcription UBF and the onion protein NopA64, a homolog of nucleolin (De Cárcer and Medina 1999). Similarly, it has been shown recently that in yeast the pre-rRNA processing, including cleavages and modifications, occurs cotranscriptionally, which contradicts the previous hypothesis that maturation of prerRNA exclusively occurred on released transcripts (Koš and Tollervey 2010). On the contrary, the simultaneous mapping of BrUTP incorporation and 5' ETS by in situ hybridization (ISH) showed that in mammalian cells transcription and primary processing events did not colocalize but occurred in separated areas of DFC (Staněk et al. 2001).

Almost fully processed pre-rRNAs leave nucleolonema and enter GC where the terminal stages of processing and assembly of ribosomal subunits occur.
Granular component

The rest of nucleolar territory is occupied by more or less densely packed ribonucleoprotein particles of $15-20 \mathrm{~nm}$ in diameter, which are pre-ribosomal subunits at various stages of their assembly (Hernandez-Verdun 2006) (Fig. 1a, b, f). In addition, at this territory, among ribosomal particles, the RNAfree nucleolar landscapes containing the protein granular complexes not connected with ribosome production may appear. It is supposed that they may constitute additional subdomains within nucleoli which play nonribosomal functions (Politz et al. 2005). Although the pre-rRNA processing starts at the sites of transcription in DFC, it continues during intranucleolar migration of not-fully matured rRNA towards GC (Nazar 2004). GC is the site of final steps of pre-rRNA maturation, as the late rRNA processing proteins, including nucleophosmin (B23) and Nop52, are localized to this area (Savino et al. 2001; Okuwaki et al. 2002). However, recently it has been shown that in human cells, the pre-rRNA processing begins in the nucleolus and ends with 18S rRNA generation in the cytoplasm (Preti et al. 2013). At the GC territory also the assembly of mature rRNAs with ribosomal proteins occurred into small and large ribosomal subunits as well as their accumulation before they are exported out of nucleoli through extranucleolar nucleoplasm to the cytoplasm (Shaw et al. 1995, 1996). Moreover, it is suggested that GC may act as ribosome transporting mechanism because of its structural framework composed of fine filamentous skeleton (Shaw et al. 1996).

The structural integration of nucleolar compartments is thought to be the key for their proper functioning. Such integration, especially well observed between GC processing proteins and DFC in active nucleoli, is sometimes called bipartite nucleolar organization (DFC and GC), it seems to be ensured by the protein kinase CK2 activity whose substrates are prerRNA-processing proteins. CK2 phosphorylation controls the GC compartmentation of the GC master phosphoprotein, B23 (Louvet et al. 2006). Experiments with the use of 5,6-dichloro$1-\beta$-D-ribofuranosylbenzimidazole (DRB), a transcription inhibitor which induces formation of GC-derived masses of late nucleolar processing proteins, suggest that rather proteinprotein interactions and protein dynamics but not processing activity and the presence of pre-rRNA, are responsible for the compartmentation of the late pre-rRNA processing machinery in GC (Louvet et al. 2005). However, orchestration of both these factors is necessary for efficient pre-rRNA processing and such a situation can occur in intact active nucleoli.

Nucleolar vacuoles

These nucleolar subdomains, also called nucleolar cavities or interstices, are rather characteristic of plants and appear mainly in the actively transcribing nucleoli, they are rarely visible in animal nucleoli. They appear as bright, often circular 
different-sized areas, usually occupying the central part of nucleoli if they are present singly in them (Fig. 1a, b, e). In light microscopic images NoV, when they are small-sized, can be easily mistaken with FCs, however, in micrographs, they possess more homogenous interior than FCs. Two types of $\mathrm{NoV}$ were distinguished in maize radicle nucleoli during germination, regular NoV that might play a role in accumulation and transport of RNPs, and vacuoles of irregular shape forming channels containing NAC, which probably participates in dispersion and activation of chromatin. Some NoV remain in contact with heterogeneous FCs (Motte et al. 1988a, 1988b).

The number and sizes of NoV are correlated with nucleolar activity, the higher activity the smaller number and bigger sizes of NoV up to one big centrally located vacuole in the most active nucleoli. Such a pattern of NoV development was correlated with the increasing time of recovery at optimal growth temperature after the soybean seedlings were treated with chilling (Stępiński 2008) (Fig. 1e). It is supposed that $\mathrm{NoV}$ are formed when a migration rate of ribosomal ribonucleoprotein particles from the nucleoli to the cytoplasm is higher than the rate of their production (Moreno-Diaz de la Espina et al. 1980; Deltour and De Barsy 1985).

In spite of extensive research on NoV functions, their roles are not fully understood, although several hypotheses have been proposed. It is supposed that they may play different roles depending on physiological needs (Mineur et al. 1998). It is impossible to expect that areas appearing during formation of NoV are just empty spaces. It would be in contradictory to the paradigm that a cell uses all space in an optimal way. NoV are supposed to be the sites of temporal sequestration and accumulation of some cellular factors (Moreno-Diaz de la Espina et al. 1980), e.g., elements of the ubiquitin-proteasome system (Stępiński 2012a), snoRNAs (Beven et al. 1996) as well as Arabidopsis U1 snRNP-specific proteins (Lorković and Barta 2008). A number of exon-junction complex (EJC) proteins, with plant-specific nucleolar localization, were identified in Arabidopsis nucleoli, and some of them were found in nucleolar cavities, so it is suggested that plant nucleolus may have additional functions in mRNA export and surveillance (Pendle et al. 2005; Brown and Shaw 2008). Moreover, soybean root meristem cell NoV contain transcripts as judged from the presence of ${ }^{3} \mathrm{H}$-uridine autoradiographic grains over the area of NoV (Stępiński 2004). Indeed, pre-ribosomal particles were also found in pea root tip cell NoV (Williams et al. 1985). In addition, the accumulation of rDNA was observed in NoV in some larger nucleoli of pea (Shaw et al. 1996).

\section{Nucleolar chromatin}

From biochemical point of view nucleoli are mostly composed of proteins (85-90\%), RNA represents only 5-10\%, and rDNA constitutes the smallest but constant part for a given species (Gerbi 1997; Shaw and Brown 2012). Low content of nucleolar DNA can be proved by the use of sensitive fluorescent staining of DNA with 4',6-diamidino-2-phenylindole (DAPI) after which the areas occupied by nucleoli remain unstained (Fig. 3a). This effect additionally results from the dispersion of chromatin in nucleoli (Shaw and Brown 2012). However, even small amounts of nucleolar chromatin in the form of small clumps of condensed chromatin as well as of thick chromatin strands can be visualized (Fig. 3b-d).

Lots of studies have been carried out on nucleolar chromatin identification and its arrangement in interphase and mitotic cells using different techniques mostly at the electron microscope level (Thiry et al. 1991; Risueño and Testillano 1994), including DNA immunogold detection with the use of monoclonal anti-DNA antibody (Yano and Sato 2002), in situ terminal deoxynucleotidyl transferase-immunogold (TdT) (Mineur et al. 1998), in situ hybridization with probes to characteristic rDNA sequences (Thiry and Thiry-Blaise 1989), as well as distinct staining methods, including osmium ammine-B complex (Motte et al. 1991; Biggiogera et al. 1996) as well as NAMA-Ur technique (Fig. 3b, d) (Testillano et al. 1991; Long et al. 2008; Shang et al. 2009; Stępiński 2013). Despite using various techniques and different research models, the results of studies concerning nucleolar chromatin localization and structure are fairly consistent. Precise determination of the higher level of organization and spatial distribution of the nucleolar chromatin is indispensible for a complete understanding and matching function of nucleolus with its structure.

\section{Plant rDNA}

In eukaryotes, the nucleolar r-genes are arranged in tandem repeats with a high copy number. Plant genomes usually have a greater number of ribosomal cistrons (r-cistrons) than animal genomes (Long and Dawid 1980; Hadjiolov 1985). Different plant species vary considerably with respect to r-gene copy number which ranges from hundreds up to several thousand, for example haploid genome of Arabidopsis thaliana possesses ca. 300-400 copies of 45S r-genes on each of two NOR-bearing chromosomes, second and fourth (Copenhaver et al. 1995; Copenhaver and Pikaard 1996), while Allium cepa around 7,000 of r-genes (Martin et al. 1989). The r-genes are present in one or more pairs of nucleolus-forming chromosomes. It is interesting that in eukaryotic cells, even in rapidly growing and proliferating ones, only about half of r-gene copies is transcriptionally active, the others are silenced (Moss and Stefanovsky 2002). In plants even smaller proportion of rRNA genes is transcriptionally utilized, e.g., in actively transcribed pea root meristem cell nucleoli about 200 300 of r-genes are active, which is about $5 \%$ of the total number of r-genes in this species (Shaw et al. 2002). 
Here, it should be noted that r-gene number influences genome integrity and chromatin regulation. Recently it has been shown that higher copy number of r-genes increases the ability to repair entire DNA in yeast (Ide et al. 2010). Moreover, the correlation between rDNA content and the ratio of heterochromatin to euchromatin has been observed in Drosophila. rDNA deletions result in loss of heterochromatinization-induced gene silencing elsewhere in the genome. (Paredes and Maggert 2009; Paredes et al. 2011). Thus, the hipothesis that extra copies of r-genes play essential role in maintaining genome stability seems to be fully justified (Kobayashi 2008).

\section{Structure of r-genes}

Each plant nucleolar r-gene codes for three rRNA species, 18S, 5.8S, and 28S rRNA. In A. thaliana, three rRNA species together with their separating internal transcribed sequences (ITS) and ETS constitute one r-repeat unit of $10 \mathrm{~kb}$ length (Copenhaver and Pikaard 1996; Raška et al. 2004). Moreover, the rRNA gene units are separated by nontranscribed intergenic spacers (IGS). In most eukaryotes, including plants, sequences for three rRNA species are highly conserved, while IGS as well as ITS and ETS are much less conserved and show far greater heterogeneity (Reeder 1992; Raška et al. 2004). The lengths of the intergenic sequences often vary in plants and animals. The plant IGS are generally shorter (2$5 \mathrm{~kb}$ ), while the animal IGS may be longer (10-30 kb) (Shaw and Brown 2012), but this is not necessarily the rule. Hence, within plants the repeat sequences may also vary in length (7$12 \mathrm{~kb}$ ), due to different lengths of nontranscribed sequences (NTSs), which are species- and cultivar-specific (Long and Dawid 1980; Ellis et al. 1984; Flavell 1986). Moreover, no equivalent NORs forming nucleoli can be present within the same species due to different lengths of NTSs as they may vary considerably even within the same NOR (Caburet et al. 2005). This is the case of Pisum sativum where two length classes of repeat units occur on four NORs, however each NOR is built of one or two repeat classes (Ellis et al. 1984) or of $A$. thaliana where three classes of IGS length variants are present at the chromosome with NOR4, while only single class at NOR2 (Copenhaver and Pikaard 1996).

\section{Nucleolar organization of chromatin}

r-chromatin forms higher-order structures depending on $\mathrm{r}$ gene activity and can localize to different subnucleolar regions. Chromatin, which is functionally related to a nucleolus, i.e., perinucleolar chromatin (NAC) as well as the intranucleolar chromatin, including FC-condensed chromatin and transcriptionally active $\mathrm{r}$-chromatin, originates from NORs (Caperta et al. 2007). All these chromatin types contain $45 \mathrm{~S}$ rRNA genes. The intranucleolar chromatin represents three different levels of structural organization, namely (1) compact clumps, (2) thick fibers, and (3) agglomerates of thin DNA filaments. The first two types show nucleosomal organization, third is devoid of nucleosomes (Derenzini et al. 2006). A nucleolus is usually accompanied by large condensed chromatin blocks, NAC, on its surface (Fig. 3b, c). This chromatin, also called nuclear rRNA genes, obviously contains r-chromatin with inactive rRNA genes (Yano and Sato 2002; Pontvianne et al. 2013). In situ hybridization with the probes to rDNA fragments, containing $18 \mathrm{~S}, 5.8 \mathrm{~S}$, and $25 \mathrm{~S}$ rRNA sequences, revealed the signals in the form of discrete domains at perinucleolar heterochromatin as well as at intranucleolar chromatin, localized to FCs, which emanated from NAC (Sato and Sato 2010). The probes also hybridized with sequences in the secondary constrictions of pea mitotic NOR-bearing chromosomes (Rawlins and Shaw 1990). However, in addition to rRNA genes, different gene families, i.a., 5S RNA and tRNA genes as well as satellite repeats were identified in human nucleolus-associated chromatin domains (NADs). The latter plays a crucial role in the assembly of perinucleolar heterochromatin (Németh et al. 2010; Németh and Längst 2011).

The arrangement of perinucleolar heterochromatic masses also seems to be not random; they are continuously harbored to the nuclear envelope through a bridge of dense chromatin (Motte et al. 1988a). It is suggested that the number of NAC knobs at the nucleolar periphery corresponds to the number of NOR-bearing chromosomes forming nucleolus, but their sizes depend on what NOR-length class they derive from (Rawlins and Shaw 1990). Such a case can be observed in quiescent cell nuclei of Zea mays in which two clumps of condensed chromatin are present at the periphery of nucleoli. The counterparts of these clumps, but smaller in sizes, are present in transcriptionally active maize cells and constitute this part of chromatin which is not involved in the formation of nucleoli but exists as inactive r-chromatin around nucleolus (Motte et al. 1991). In Z. mays, NORs, on each of two nucleoliforming chromosomes, consist of two parts, (1) the secondary constriction and (2) the heterochromatic segment adjacent to it. Great majority of inactive rRNA genes forms nucleolar peripheral NAC and they are located to heterochromatic segments of NOR, while active r-genes, which are engaged in nucleolus formation, occupy the secondary constriction of NOR (Motte et al. 1988a). In addition to NAC, the mammal nucleolus is encircled by the shell of perinucleolar heterochromatin which frequently contains centromeric and pericentromeric chromosomal regions (Németh and Längst 2011). This perinucleolar region is also mentioned in "Other nucleolar subcompartments."

The chromatin emanating from NAC forms chains of small chromatic spots, resembling a string with threaded beads, which frequently extends and localizes to FCs. It is especially well visible when a cell enters prophase and simultaneously 
the nucleolar segregation occurs. Then FCs develop to fuse and a channel-like structure is formed containing clusters of dense chromatin derived from NAC (Fig. 3c) (Yano and Sato 2000). The intranucleolar-condensed chromatin was found to reside in the central parts of mainly large heterogeneous FCs (Fig. 1c) due to a great number of r-genes in plant nucleoli (Yano and Sato 2000). This condensed r-chromatin could remain silent for a longer time, but it is still ready to be woken up when needed (Risueño et al. 1982). It seems probable that when nucleolar transcriptional activity increases, the incompetent chromatin turns into transcriptionally active r-genes which are disentangled and released from the FC-condensed chromatin (Yano and Sato 2002), thus the number of active $45 \mathrm{~S}$ rRNA genes may change according to the physiological needs of the cell (McStay and Grummt 2008; Tucker et al. 2010). It means that the content of nucleolar-condensed chromatin can change according to the transcriptional activity of nucleoli. Indeed, such a correlation was observed in the nucleoli of soybean plants subjected to chilling, when nucleolar transcriptional activity was low, the increase in the content of condensed chromatin was observed, whereas when the seedlings were transferred from chilling to the optimal growth temperature to recover then the nucleoli showed extra high activity and the amount of the condensed chromatin decreased in comparison to the situation when the plants grew continuously at optimal temperature where nucleolar transcriptional activity was at the normal level and the nucleolar-condensed chromatin content was intermediate (Stepiński 2012b, 2013). Moreover, it is hypothesized that in the nucleoli with growing transcriptional activity in which ribosomal genes are transcribed continuously, the temporarily inactive chromatin, residing in FCs in the decondensed state, might be ready to use (Risueño et al. 1982). The loops of active r-chromatin are not uniformly arranged around FC periphery and FC-DFC border zone but they are limited to discrete areas (De Cárcer and Medina 1999). Recently, it was shown that in A. thaliana, the inactive $r$-genes are presumably concentrated in the perinucleolar region whereas the active genes occupy the nucleolar interior. Transcriptional status of these genes is changeable depending on the needs, hence it is suggested that just activated r-genes are introduced into nucleoli, while inactivated ones are excluded from nucleoli and incorporated into perinucleolar chromatin (Pontvianne et al. 2013). The authors do not mention inactive FC r-chromatin, however a small fraction of silenced r-RNA genes located in cis to active genes was detected in the nucleoli of $A$. thaliana. It is possible that $\mathrm{FC}$ localization of condensed $\mathrm{r}$-genes depends on the great total number of r-gene or of only repressed r-genes.

In some species, chromatin resides not only in $\mathrm{FC}$ but also in DFC however close to FC, while in others solely in FCs. It can be explained by the high redundancy of r-genes getting out of FCs, as it is in proliferating A. cepa cells whose genome contains about 7,000 copies of r-genes. Conversely, in some species with the excess of r-chromatin, it can be stored as perinucleolar chromatin permanently blocked in transcription, but it is not the case of onion plants where, as it is suggested, all r-genes are involved in nucleolar transcriptional activity and they do not form perinucleolar clumps of chromatin (Martin et al. 1989). However, in quiescent cells, despite a great number of r-genes, r-chromatin does not occur in any region of DFC (Martin et al. 1989). Moreover, it should not be surprising that the chromatin strands or loops can also be seen in DFC on EM sections, as nucleolar chromatin remains continuity running from one $\mathrm{FC}$ to another through duct-like structures (Fig. 3d) (Medina et al. 2000).

It should be noted that in addition to r-chromatin, also other DNA can be present in nucleolus (Németh and Längst 2011). The role of this intranucleolar chromatin that does not correspond to rDNA is unknown. However, it may serve as anchorage sites for various macromolecules, similarly as some proteins colocalize with r-chromatin (Zougman et al. 2011). Occasionally, spots of condensed chromatin could be seen in other regions of nucleoli but this chromatin might correspond to interdigitation of extranucleolar-condensed chromatin into nucleolar interior (Martin et al. 1989).

Despite differences in the total number r-genes both in active and repressed form in various species as well as in transcriptional activity under given situation, the organization of nucleolar chromatin seems to be common for higher plants as the distribution and arrangement of the ribosomal chromatin are similar for both mono- and dicotyledonous species (Motte et al. 1991).

\section{Control of rDNA competence}

Nucleolar chromatin, regardless of nucleolar subregion it occupies or functional state it represents, is subjected to many factors influencing its structure and competence.

Epigenetic modification of r-chromatin. Significant mechanisms connected with rRNA biosynthesis establish the transcriptional competence state of r-chromatin through switching r-genes "on" and "off." During controlling the number of active and inactive r-cistrons, much attention is paid to epigenetic adjustment (Layat et al. 2012). Regulation of these two fractions of r-genes concerns both interspecific hybrids or allopolyploids in which the set of NORs with active or repressed r-genes is inherited from only one parent, a phenomenon known as nucleolar dominance, and nonhybrid organisms which in addition to the silent rDNA loci also contain loci with both transcribed and repressed rRNA genes (Santoro 2005; McStay 2006; Preuss and Pikaard 2007). rRNA gene silencing regulation in both groups might lie under similar epigenetic control but can differ in details (Pontvianne et al. 2012). In plants, chemical modification of chromatin, i.e., methylation of $\mathrm{CpG}, \mathrm{CpNpG}$, and $\mathrm{CpNpN}(\mathrm{N}=\mathrm{A}, \mathrm{C}$, or $\mathrm{T})$ in rDNA as well as posttranslational modifications of 
histones, influence chromatin structure resulting in transcriptionally competent or incompetent chromatin (Chen and Pikaard 1997; Richards and Elgin 2002; Lachner et al. 2003; Inagaki and Kukutani 2010). With regard to the epigenetic control, different regulatory noncoding RNAs guide rDNA transcription in plants and animals - siRNA in the former and pRNA (Mayer et al. 2006; Lempiäinen and Shore 2009; Tucker et al. 2010) together with a nucleolar remodeling complex (NoRC) in the latter (Strohner et al. 2004; Santoro and Grummt 2005).

\section{Nucleolin, a modulator of r-chromatin structure}

Major nucleolar protein, nucleolin, is implicated in many aspects of ribosome biosynthesis (Ginisty et al. 1999). In this regard, it was also found to be a new factor regulating chromatin structure-mediated rDNA transcription. At-NUC-L1, an A. thaliana nucleolin-like protein, specifically binds to promoter sequences of r-genes and directs rDNA transcription from the transcription initiation sites. It controls r-chromatin condensation and homeostatic rRNA gene expression (Pontvianne et al. 2007). Furthermore, it turned out that nucleolin played a new role in controlling active and silenced rRNA gene variants in $A$. thaliana in which IGS transcription and symmetric DNA methylation were required (Pontvianne et al. 2010).

\section{Cytoskeleton elements in r-gene transcription}

Lately researches have pointed to direct involvement of motor proteins, actin and nuclear myosin 1 (NM1), in transcription initiation, including rDNA transcription. The proteins act as molecular motors to coordinate the assembly of RNA polymerase I at the gene promoter. Actin interacts directly with the polymerase I complex whereas NM1 associates with the complex by means of phosphorylated form of transcription initiation factor (TIF-IA). They are thought to play the physiological role in the growth-dependent regulation of rDNA transcription. Up till now, the role of motor proteins has been implicated in insects and mammals, however it cannot be excluded that they share a common function in all eukaryotes, including plants (Philimonenko et al. 2004, 2010; Visa 2005). More recently, it has been shown that NM1 takes part in the facilitation of the epigenetic chromatin modifications through recruitment of histone acetyl transferases. This cooperation leads to nucleosome repositioning resulting in the permissive chromatin structure required for activation of the rRNA gene transcription (Sarshad et al. 2013). Synergistic action for all of these factors, which are accompanied by many other regulatory macromolecules, is required for rDNA transcription to be effective. Molecular details associated with this topic are beyond the scope of this article, and readers interested in this subject will find them in available papers (Grummt 2003;
Russell and Zomerdijk 2005; Engel et al. 2013; Sarshad et al. 2013).

\section{Other nucleolar subcompartments}

It could seem that the nucleolar structural organization and subcompartmentation is exclusively dedicated to ribosome production. Extending research of new nucleolar localization and accumulation of various components taking part in just discovered nucleolar functions, allows on the one hand to attribute new function to well-known subcompartments, on the other to identify quite new nucleolar subregions. Any nuclear domains, nuclear bodies, or nucleolar subdomains are formed by specific interaction between proteins or between proteins and ribonucleoproteins (Dundr and Misteli 2010; Mao et al. 2011), furthermore, membraneless nucleoli may create a convenient site and environment for the location of components and such interactions, in consequence for functions played by them. The domains such as Cajal bodies and intranucleolar bodies, aggresomes, or perinucleolar heterochromatin compartments have found nucleoli to be an attractive harbor for them (Table 3).

The traditionally understood nucleolar compartments or additional nucleolar bodies or aggregates are highly dynamic structures implicated in modulation of many cellular activities. They are constantly present or appear de novo as a result of action of various stimuli or treatments. Some of them are found in most cells, while others occur rarely or are characteristic of specific cell types. Why is it that only nucleoli become a multifunctional organelle? It is obvious that they must be specific structures in whose interior at different subcompartments or regions with unique microenvironments exist in order to ensure optimal conditions for all these functions. From ultrastructural point of view, the most appropriate compartments seem to be those with low density, which are easily available for molecules, namely NoV or cavities, FCs as well as GC. Indeed, growing literature data show that these regions are the most frequent sites for proteins to reside. The mechanisms that control the compartmentation of nucleolar proteins and macromolecules are still poorly understood with respect to plants. However, in the case of human cells, noncoding RNAs (ncRNAs) which are transcribed from the stimulus-specific sequences of the rDNA-locus-derived IGS contribute to capturing and immobilization of nucleolar detention sequence (NoDS)-containing proteins within the nucleolus (Audas et al. 2012).

Regular tripartite pattern of nucleoli is restricted to ribosome biosynthesis till now. Given that the nucleolus is a multifunctional organelle, it would be proper to extend this simplified model with additional subdomains connected with new functions. Furthermore, the adage that the nucleolus is a structure "formed by the act of building a ribosome" sounds 
Table 3 Characteristics of other then traditional subdomains or structures distinguished in the nucleoli of plant (Pl) or animal (An) cells

\begin{tabular}{|c|c|c|c|c|c|}
\hline \multirow[t]{2}{*}{ Subdomain/structure } & \multirow[t]{2}{*}{ Function } & \multirow[t]{2}{*}{ Composition } & \multirow{2}{*}{$\begin{array}{l}\text { Morphological } \\
\text { characteristics }\end{array}$} & \multicolumn{2}{|c|}{ System } \\
\hline & & & & $\mathrm{Pl}$ & An \\
\hline $\begin{array}{l}\text { Cajal bodies (CB) } \\
\text { (Fig. 1b) }\end{array}$ & $\begin{array}{l}\text { Modification of proteins and RNAs, } \\
\text { telomerase maturation, histone mRNA } \\
\text { processing (Bassett 2012; Machyna } \\
\text { et al. 2013) siRNA and miRNA } \\
\text { biogenesis (Pontes and Pikaard 2008), } \\
\text { cell cycle regulation, and response to } \\
\text { stress (Boulon et al. 2010) }\end{array}$ & Various RNA species, proteins & $\begin{array}{l}0.5-1 \mu \mathrm{m} \text { in diameter, } \\
\text { spherical-shaped, } \\
1-10 \text { in nucleus }\end{array}$ & + & + \\
\hline Nucleolar aggresomes & $\begin{array}{l}\text { Stress response (Latonen et al. 2011), } \\
\text { storage, and/or degradation of RNA } \\
\text { (Costanzo et al. 2011) }\end{array}$ & $\begin{array}{l}\text { Proteins: p53, pRb, ubiquitin and its } \\
\text { conjugates, UPS components, } \\
\text { polyadenylated RNA, cell cycle } \\
\text { cyclins, and kinases (Costanzo } \\
\text { et al. 2011), RNAse A, and RNA } \\
\text { (Mao et al. 2011) }\end{array}$ & $\begin{array}{l}\text { Roundish, fibrillar, } \\
\text { homogenous areas } \\
\text { located near FCs or in } \\
\text { the nucleolar periphery }\end{array}$ & - & + \\
\hline \multirow{2}{*}{$\begin{array}{l}\text { Perinucleolar region } \\
\text { with nucleolus- } \\
\text { associated chromatin } \\
\text { domains (NADs) } \\
\text { (Fig. 3b) }\end{array}$} & $\begin{array}{l}\text { Silence of r-genes and of nonribosomal } \\
\text { genomic regions, constraining the } \\
\text { movement of DNA sequences } \\
\text { (Mao et al. 2011) }\end{array}$ & Perinucleolar heterochromatin & $\begin{array}{l}\text { Nucleolar surface } \\
\text { located }\end{array}$ & + & + \\
\hline & Gene expression (Németh et al. 2010) & Active 5S RNA and tRNA genes & & - & + \\
\hline $\begin{array}{l}\text { Perinucleolar compartment } \\
\text { (PNC) }\end{array}$ & RNA metabolism (Spector 2001) & Small RNAs, RNA-binding proteins & Nucleolar surface located & - & + \\
\hline Intranucleolar body (INB) & $\begin{array}{l}\text { rDNA transcription regulation } \\
\text { (Hutten et al. 2011) }\end{array}$ & Mainly proteins & $\begin{array}{l}\text { Corresponds to nucleolar } \\
\text { cavity, } 0.4 \text { to } 1.6 \mu \mathrm{m} \text { in } \\
\text { diameter }\end{array}$ & - & + \\
\hline
\end{tabular}

“+” identified, "-” not determined or not applicable

somewhat archaic not only in the context of its plurifunctionality, but also with respect to the ribosome production itself. Recently it has been evidenced that rDNA sequences, especially UBF-binding sites with r-gene transcription units, are sufficient to form NORs capable of biogenesis of nucleoli in human cells (Grob et al. 2014).

\section{The nucleolus in noncanonical roles}

In addition to the main function of nucleoli, ribosome biosynthesis, they are also involved in many other key cellular activities. Some of them are concisely presented in Table 4. Attributing nonconventional roles to nucleoli is mainly based on the discovery of a vast number of various proteins and ribonucleoprotein complexes, not connected with ribosome production, residing in them. Intense proteomic analyses both of human (Andersen et al. 2002; Ahmad et al. 2009) and A. thaliana (Pendle et al. 2005) nucleoli enabled identification of these proteins. For some of them, their functions were established and this allowed to attribute these functions to nucleoli, but the other proteins wait for validation of their putative roles. Different nucleolar localization and accumulation of various macromolecules seem to imply different processes, an thus, the nucleolus represents specific spatial arrangement for many various functions, so the organization of the nucleolus seems to be much more complex than it was previously thought.

The preparation of great number of various RNAs and RNPs (Table 4) and their preservation in plant nucleoli, under physiological conditions or in response to internal or external stimuli, as well as posttranslational modifications of proteins, such as sumoylation and phosphorylation, controlling their activities, imply that these organelles could have the crucial roles in regulatory activities, such as gene expression, in order to ensure optimal functioning of cells and/or their adjustment to actually dominating conditions. Moreover, some nucleolar functions result from the fact that nucleoli are the sites of temporal inactivation through nucleolar sequestration of enzymatic or regulatory proteins associated with those functions (Table 4). Then, they are released at the given situation at the right time in order to exert the established effect (Olson et al. 2000; Visintin and Amon 2000; Costanzo et al. 2011; Audas et al. 2012). Large portion of new and interesting information, also referring to the molecular level, focused mainly on mammalian nucleoli as reactors for ribosome production as well as structures playing noncanonical functions Readers will find in some extensive reviews (Pederson 1998, 2010; Olson 2004; Raška et al. 2006b; Boisvert et al. 2007; Brown and Shaw 2008; Sirri et al. 2008; Hernandez-Verdun et al. 2010; Shaw and Brown 2012). 
Table 4 Ribosome-associated and nonconventional functions/processes of the plant and animal (or yeast) nucleoli and nucleolar compartments (if determined) ascribed to these functions

\begin{tabular}{|c|c|c|}
\hline \multirow[t]{2}{*}{ Function/process } & \multicolumn{2}{|l|}{ Nucleoli in } \\
\hline & Plants & Animals \\
\hline \multirow[t]{2}{*}{ rDNA transcription } & + (González-Melendi et al. 2001) & + (Koberna et al. 2002) \\
\hline & $\mathrm{FC} / \mathrm{DFC}$ border & FC, DFC, or FC/DFC border (Huang 2002) \\
\hline \multirow{2}{*}{$\begin{array}{l}\text { rRNA processing and ribosome } \\
\text { subunits assembly }\end{array}$} & + (Staněk et al. 2001) & + (Beven et al. 1996) \\
\hline & $\mathrm{DFC}$ and $\mathrm{GC}$ & $\mathrm{DFC}$ and $\mathrm{GC}$ \\
\hline \multirow[t]{2}{*}{ Viral infections } & + (Taliansky et al. 2011; Kim et al 2007) & + (Dove et al. 2006; Emmott et al. 2008) \\
\hline & DFC (Rakitina et al. 2011) & DFC (Dove et al. 2006) \\
\hline \multirow[t]{2}{*}{ HIV proteins/mRNA } & - & $+($ Olson and Dundr 2005) \\
\hline & & $\mathrm{DFC}$ or $\mathrm{GC}$ \\
\hline Stress sensor and response & $\begin{array}{l}\text { Changes of morphology and composition } \\
\text { (Stępiński 2009, 2010) }\end{array}$ & + (Boulon et al. 2010) \\
\hline \multirow[t]{2}{*}{ - p53 pathway } & - & $\begin{array}{l}+ \text { (Olson 2004; Mayer and Grummt 2005; } \\
\quad \text { Suzuki et al. 2012; Krüger and Scheer 2010) }\end{array}$ \\
\hline & & nucleolar cavity (Krüger and Scheer 2010) \\
\hline - Without p53 pathway & - & $+($ Olausson et al. 2012) \\
\hline $\begin{array}{l}\text { Regulation of tumor suppressor } \\
\text { and oncogenic activity }\end{array}$ & - & + (Tsai and McKay 2002) \\
\hline Cell cycle regulation & \multicolumn{2}{|l|}{$\begin{array}{l}\text { Yeast (Cockell and Gasser 1999; } \\
\text { Visintin et al. 1999; Visintin and } \\
\text { Amon 2000) }\end{array}$} \\
\hline Control of aging & - & $+($ Guarente 1997) \\
\hline Promotion of protein homeostasis via chaperones & - & + (Bański et al. 2010) \\
\hline \multirow[t]{2}{*}{$\begin{array}{l}\text { Metabolism, modifications, assembly, } \\
\text { or transport of RNAs and/or RNA-containing } \\
\text { complexes } \\
\text {-mRNA }\end{array}$} & $\begin{array}{l}+ \text { Brown and Shaw 2008; } \\
\text { Shaw and Brown } 2012\end{array}$ & + (Brown and Shaw 2008; Shaw and Brown 2012) \\
\hline & $+($ Kim et al. 2009) & + (Gururajan et al. 1994; Názer et al. 2012) \\
\hline -Signal recognition particles (SRP) RNA & - & + (Politz et al. 2000; Jacobson and Pederson 1998) \\
\hline -Small RNAs (snRNAs and snoRNAs) & $+($ Kim et al. 2010) & $+($ Gerbi et al. 2003) \\
\hline \multirow{3}{*}{$\begin{array}{l}\text {-tRNAs/RNase P proteins: } \\
\text { - Rpp14 and Rpp29 } \\
\text { - Rpp38 }\end{array}$} & Yeast (Bertrand et al. (1998) & + (Jarrous et al. 1999) \\
\hline & & $\mathrm{DFC}$ \\
\hline & & Allover nucleolus \\
\hline \multirow[t]{2}{*}{-Regulatory RNAs (siRNAs and miRNAs) } & + (Pontes et al. 2013) & + (Politz et al. 2009) \\
\hline & Nucleolar periphery and CBs & \\
\hline -Modulation of telomerase function & - & + (Wang et al. 2010) \\
\hline $\begin{array}{l}\text { Exon-junction complex (EJC) proteins in } \\
\text { mRNA metabolism }\end{array}$ & $\begin{array}{l}+ \text { (Brown and Shaw 2008; } \\
\text { Pendle et al. 2005) }\end{array}$ & - \\
\hline
\end{tabular}

“+” identified, “-” not determined or not applicable

Although the nucleoli seem to be conservative structures with respect to their functionality, these organelles show high variability in animal, plant, and yeast systems not only from morphological point of view but also due to ribosome biosynthesis itself (Shaw et al. 1996; Léger-Silvestre et al. 1997; Thiry and Lafontaine 2005; Raška et al. 2006a; HernandezVerdun et al. 2010). Moreover, additional activities of the nucleoli are not obviously related to all eukaryotes. Apparent similarities seem to involve few common nucleolar duties. Most of the nonconventional employments have been attributed to the animal nucleoli, some to plants, and some are shared by all eukaryotic kingdoms. Does such a situation result from the fact that the human nucleoli are really incomparably more abundant in proteins (Andersen et al. 2002; Ahmad et al. 2009) than those in plants (Pendle et al. 2005) or from the fact that the research concerning animals and humans is treated with more attention because of its biomedical importance while plant research is still underestimated? The question is open and the nearest future will bring the answer. 
Identification of new proteins and nonprotein components residing in the nucleolus which points out to extra activities of nucleoli, and establishment of their significance not only for functioning of the nucleolus itself but also of the whole cell is undoubtedly a great achievement. However, this is an incomplete success. Nucleolar proteomics approaches supply only qualitative and possibly quantitative information on a given component and concern the entire nucleolus. Such knowledge regarding only "macrolocalization," in this case nucleolus as the whole, is perhaps sufficient for biochemists; however, it does not satisfy the cytological researchers. The knowledge of the role of a given biomolecule needs to be supplemented with its transition pathways from the site of synthesis to the final destination in a specific nucleolar subcompartment, i.e., to the site of its accumulation and action, and only then it would be possible to precisely attribute the function to the subdomain. Although biochemical and molecular investigations are considerably ahead of cytochemical and morphological ones and knowledge of nucleolar processes at the molecular level is now available, their spatial organization is still missing. Hence most factors, even with the determined role, have not been attributed to the right nucleolar subcompartment so far and data on this subject are scarce in literature. Greater number of investigations at electron microscopy level with the use of immunogold technique as well as GFP-tagged proteins would undoubtedly provide lacking information and make it possible to work up a nucleolar ultrastructural map at the molecular level.

\section{Conclusion}

The nucleolus is a very dynamic structure which results not only from the fact that it is a transit pathway of the great number of macromolecules but also because it readily responds to any deviations from regular conditions or to transition through phases of the cell cycle which is manifested with alterations of its structure, size and composition. The morphology of plant nucleoli reflects their activities which often depend on environmental conditions which plants are exposed to at the given moment. That is why the structure of a nucleolus cannot be precisely defined, even within a given species, unless the conditions under which a nucleolus is described are specified. Furthermore, plant and animal nucleoli, changing their composition and structure under certain unfavourable conditions resulting in nucleolar stress, could serve as indicators that something wrong happens to the cell, if the biochemical and/or morphological parameters of nucleoli would be characterized for a given treatment. Thus, ultrastructural and morphological studies of the nucleoli appear to be a valuable source of information, supplementary to biochemical data, facilitating the evaluation of the physiological state of a cell.
It is believed that the regular structure of an interphase nucleolus is maintained by the activity of RNA polymerase I which results in rRNA synthesis and by assembly of rRNA with proteins into ribosomal subunits. However, yeast mutants, showing irregular structure of nucleoli, are able to produce ribosomes (Nierras et al. 1997). Generally, the functionality of nucleoli, including ribosome biosynthesis, seems to be the key feature, while their regular structures are of lesser importance.

Proteomics of nucleoli showed that these organelles are not only the site of temporal sequestration and accumulation of a vast number of nucleolar and ribosomal proteins or ribonucleoproteins but also of macromolecules with nonribosomal functions which pass the nucleoli and reside in them for a very short time. Although research in recent years allowed to uncover the roles of some of these biomolecules that impose to nucleoli the additional functions in key cellular processes, functions of other proteins have not been defined so far. Therefore, attribution of new functions to nucleoli seems to be a matter of time. Moreover, the activities that were ascribed to nucleoli in the last two decades apply only to some organism groups. For example, it is difficult to imagine that typical oncogenic activity, which is characteristic of the animal nucleoli, could be attributed to plants. Thus, nucleolar functions should not be generalized except for those which are common for all nucleoli- the biosynthesis of ribosomes.

Certainly in the near future, nucleolar researchers will employ new experimental methods enabling further elucidation or supplementation of relationships between structural components of nucleoli and molecular processes associated not only with ribosome biosynthesis, it also seems that some previous dogmas will be refuted.

Conflict of interest The author declares no conflict of interest.

Open Access This article is distributed under the terms of the Creative Commons Attribution License which permits any use, distribution, and reproduction in any medium, provided the original author(s) and the source are credited.

\section{References}

Ahmad Y, Boisvert FM, Gregor P, Cobley A, Lamond AI (2009) NOPdb: Nucleolar proteome database-2008 update. Nucleic Acids Res 37: D181-D184

Amin MA, Matsunaga S, Ma N, Takata H, Yokoyama M, Uchiyama S, Fukui K (2007) Fibrillarin, a nucleolar protein, is required for normal nuclear morphology and cellular growth in HeLa cells. Biochem Biophys Res Commun 360:320-326

Andersen JS, Lyon CE, Fox AH, Leung AK, Lam YW, Steen H, Mann M, Lamond AI (2002) Directed proteomic analysis of the human nucleolus. Curr Biol 12:1-11 
Audas TE, Jacob MD, Lee S (2012) Immobilization of proteins in the nucleolus by ribosomal intergenic noncoding RNA. Mol Cell 45: $147-157$

Bański P, Kodiha M, Stochaj U (2010) Chaperones and multitasking proteins in the nucleolus: networking together for survival? Trends Biochem Sci 35:361-367

Barneche F, Steinmetz F, Echeverria M (2000) Fibrillarin genes encode both a conserved nucleolar protein and a novel small nucleolar RNA involved in ribosomal RNA methylation in Arabidopsis thaliana. $\mathrm{J}$ Biol Chem 275P:27212-27220

Bassett CL (2012) Cajal bodies and plant RNA metabolism. Crit Rev Plant Sci 31:258-270

Bassy O, Jiménez-Garcia LF, Echeverria OM, Vázquez-Nin GH, Moreno Díaz de la Espina S (2000) High resolution detection of rRNA and rDNA in plant nucleoli with different activities by in situ hybridization. Biol Cell 92:59-70

Bertrand E, Houser-Scott F, Kendall A, Singer RH, Engelke DR (1998) Nucleolar localization of early tRNA processing. Genes Dev 12: 2463-2468

Beven AF, Lee R, Razaz M, Leader DJ, Brown JWS, Shaw PJ (1996) The organization of ribosomal RNA processing correlates with the distribution of nucleolar snRNAs. J Cell Sci 109:1241-1251

Biggiogera M, Courtens JL, Derenzini M, Fakan S, Hernandez-Verdun D, Risueno MC, Soyer-Gobillard MO (1996) Osmium ammine: Review of current applications to visualize DNA in electron microscopy. Biol Cell 87:121-132

Boisvert FM, van Koningsbruggen S, Navascués J, Lamond AI (2007) The multifunctional nucleolus. Nat Rev Mol Cell Biol 8:574-585

Boulon S, Westman BJ, Hutten S, Boisvert FM, Lamond AI (2010) The nucleolus under stress. Mol Cell 40:216-227

Brown JWS, Shaw PJ (1998) Small nucleolar RNAs and pre-rRNA processing in plants. Plant Cell 10:649-657

Brown JWS, Shaw PJ (2008) The role of the plant nucleolus in premRNA processing. Curr Top Microbiol Immunol 326:291-311

Caburet I, Conti C, Schurra C, Lebofsky R, Edelstein SJ, Bensimon A (2005) Human ribosomal RNA gene arrays display a broad range of palindromic structures. Genome Res 15:1079-1085

Caperta AD, Neves N, Viegas W, Pikaard CS, Preuss S (2007) Relationship between transcription, silver staining, and chromatin organization of nucleolar organizers in Secale cereale. Protoplasma 232:55-59

Carron C, Balor S, Delavoie F, Plisson-Chastang C, Faubladier M, Gleizes PE, O'Donohue MF (2012) Post-mitotic dynamics of prenucleolar bodies is driven by pre-rRNA processing. J Cell Sci 125: $4532-4542$

Casafont I, Bengoechea R, Navascués J, Pena E, Berciano M, Lafarga M (2007) The giant fibrillar center: A nucleolar structure enriched in upstream binding factor (UBF) that appears in transcriptionally more active sensory ganglia neurons. J Struct Biol 159:451-461

Chen M, Jiang P (2004) Altered subcellular distribution of nucleolar protein fibrillarin by actinomycin D in HEp-2 cells. Acta Pharmacol Sin 25:902-906

Chen ZJ, Pikaard CS (1997) Epigenetic silencing of RNA polymerase I transcription: a role for DNA methylation and histone modification in nucleolar dominance. Genes Dev 11:2124-2136

Cheutin T, O'Donohue MF, Beorchia A, Vandelaer M, Kaplan H, Defever B, Ploton D, Thity M (2002) Three-dimensional organization of active rRNA genes within the nucleolus. J Cell Sci 115: 3297-3307

Cmarko D, Smigova J, Minichova L, Popov A (2008) Nucleolus: the ribosome factory. Histol Histopathol 23:1291-1298

Cockell MM, Gasser SM (1999) The nucleolus: nucleolar space for RENT. Curr Biol 9:R575-R576

Copenhaver GP, Pikaard CS (1996) Two-dimensional RFLP analyses reveal megabase-sized clusters of rRNA gene variants in Arabidopsis thaliana, suggesting local spreading of variants as the mode for gene homogenization during concerted evolution. Plant $\mathrm{J}$ 9:273-282

Copenhaver GP, Doelling JH, Gens JH, Pikaard CS (1995) Use of RFLPs larger than $100 \mathrm{kbp}$ to map the position and internal organization of the nucleolus organizer region on chromosome 2 in Arabidopsis thaliana. Plant J 7:273-286

Costanzo M, Cisterna B, Zharskaya OO, Zatsepina OV, Biggiogera M (2011) Discrete foci containing RNase A are found in nucleoli of HeLa cells aged in culture. Eur J Histochem 55:82-84

Cremer T, Cremer M, Dietzel S, Müller S, Solovei I, Fakan S (2006) Chromosome territories - a functional nuclear landscape. Curr Opin Cell Biol 18:307-316

Cvačková Z, Albring KF, Koberna K, Ligasová A, Huber O, Raška I, Staněk D (2008) Pontin is localized in nucleolar fibrillar centers. Chromosoma 117:487-497

De Cárcer G, Medina FJ (1999) Simultaneous localization of transcription and early processing markers allows dissection of functional domains in the plant cell nucleolus. J Str Biol 128:139-151

Deltour R, De Barsy T (1985) Nucleolar activation and vacuolation in embryo radicle cells during early germination. J Cell Sci 76:67-83

Deltour R, Mosen H (1987) Proposals for the macromolecular organization of higher plant nucleolonema. Biol Cell 60:75-86

Deltour R, Motte P (1990) The nucleolonema of plant and animal cells: a comparison. Biol Cell 68:5-11

Derenzini M, Treré D, Pession A, Govoni M, Sirri V, Chieco P (2000) Nucleolar size indicates the rapidity of cell proliferation in cancer tissues. J Pathol 191:181-186

Derenzini M, Pasquinelli G, O'Donohue MF, Ploton D, Thiry M (2006) Structural and functional organization of ribosomal genes within the mammalian cell nucleolus. J Histochem Cytochem 54:131-145

Dove BK, You JH, Reed ML, Emmett SR, Brooks G, Hiscox JA (2006) Changes in nucleolar morphology and proteins during infections with the coronavirus infectious bronchitis virus. Cell Microbiol 8: $1147-1157$

Dunbar DA, Wormsley S, Lowe TM, Baserga SJ (2000) Fibrillarin associated box C/D small nucleolar RNAs in Trypanosoma brucei. J Biol Chem 275:14767-14776

Dundr M, Misteli T (2010) Biogenesis of nuclear bodies. Cold Spring Harb Perspect Biol 2:a000711. doi:10.1101/cshperspect.a000711

Dundr M, Olson MOJ (1998) Partially processed pre-rRNA is preserved in association with processing components in nucleolus-derived foci during mitosis. Mol Biol Cell 9:2407-2422

Dundr M, Raska I (1993) Nonisotopic ultrastructural mapping of transcription sites within the nucleolus. Exp Cell Res 208:275-281

Ellis THN, Davies DR, Castleton JA, Bedford ID (1984) The organization and genetics of rDNA length variants in peas. Chromosoma 91: $74-81$

Emmot E, Dove BK, Howell G, Chappell LA, Reed ML, Boyne JR, You JH, Brooks G, Whitehous A, Hiscox JA (2008) Viral nucleolar localisation signals determine dynamic trafficking within the nucleolus. Virology 380:191-202

Engel C, Sainsbury S, Cheung AC, Kostrewa D, Cramer P (2013) RNA polymerase I structure and transcription regulation. Nature. doi:10. 1038/nature 12712

Fatica A, Galardi S, Altieri F, Bozzoni I (2000) Fibrillarin binds directly and specifically to U16 box C/D snoRNA. RNA 6:88-95

Fernandez-Donoso R, Berrios S, Pincheira J (1979) Position of the nucleolus within the nuclei of pachytene spermatocytes of Dromiciops australis and Marmosa elegans (DidelphoideaMarsupialia). Experientia 35:1021-1023

Flavell RB (1986) The structure and control of expression of ribosomal RNA genes. In: Miflin BJ (ed) Plant molecular and cell biology. Oxford University Press, Oxford, pp 251-274

Fromont-Racine M, Senger B, Saveanu C, Fasiolo F (2003) Ribosome assembly in eukaryotes. Gene 313:17-42 
Gerbi SA (1997) The nucleolus: then and now. Chromosoma 105:385387

Gerbi SA, Borovjagin AV, Lange TS (2003) The nucleolus: a site ribonucleoprotein maturation. Curr Opin Cell Biol 15:318-325

Ginisty H, Sicard H, Roger B, Bouvet P (1999) Structure and function of nucleolin. J Cell Sci 112:761-772

Goessens G (1984) Nucleolar structure. Int Rev Cytol 87:107-158

Goessens G, Lepoint A (1979) The nucleolus-organizing regions (NORs): recent data and hypotheses. Biol Cell 35:211-220

González-Camacho F, Medina FJ (2004) Identification of specific plant nucleolar phosphoproteins in a functional proteomic analysis. Proteomics 4:407-417

González-Camacho F, Medina FJ (2006) The nucleolar structure and the activity of NopA100, a nucleolin-like protein, during the cell cycle in proliferating plant cells. Histochem Cell Biol 125:139-153

González-Melendi P, Wells B, Beven AF, Shaw PJ (2001) Single ribosomal transcription units are linear, compacted Christmas trees in plant nucleoli. Plant J 27:223-233

Grob A, Colleran C, McStay B (2014) Construction of synthetic nucleoli in human cells reveals how a major functional nuclear domain is formed and propagated through cell division. Genes Dev 28:220 230

Grummt I (2003) Life on a planet of its own: regulation of RNA polymerase I transcription in the nucleolus. Genes Dev 17:1691-1702

Grummt I, Pikaard CS (2003) Epigenetic mechanisms controlling RNA polymerase I transcription. Nat Rev Mol Cell Biol 4:641-649

Guarente L (1997) Link between aging and the nucleolus. Genes Dev 11: 2449-2455

Gururajan R, Mathews L, Longo FJ, Weeks DL (1994) An3 mRNA encodes an RNA helicase that colocalizes with nucleoli in Xenopus oocytes in a stage-specific manner. Proc Natl Acad Sci U S A 91:2056-2060

Hadjiolov AA (1985) The nucleolus and ribosome biogenesis. In: Goldstein L, Portrer KR, Sitte P (eds) Beerman AM. Cell biology monographs, New York, pp 1-263

Heliot L, Kaplan H, Lucas L, Klein C, Beorchia A, Doco-Fenzy M, Menager M, Thiry M, O’Donohue MF, Ploton D (1997) Electron tomography of metaphase nucleolar organizer regions: evidence for a twisted-loop organization. Mol Biol Cell 8:2199-2216

Henriquez R, Blobel G, Aris JP (1990) Isolation and sequencing of NOP1. J Biol Chem 265:2209-2215

Hernandez-Verdun D (1991) Commentary: the nucleolus today. J Cell Sci 99:465-471

Hernandez-Verdun D (2006) Nucleolus: from structure to dynamics. Histochem Cell Biol 125:127-137

Hernandez-Verdun D (2011) Assembly and disassembly of the nucleolus during the cell cycle. Nucleus 2:189-194

Hernandez-Verdun D, Roussel P, Gebrane-Younes G (2002) Emerging concepts of nucleolar assembly. J Cell Sci 115:2265-2270

Hernandez-Verdun D, Roussel P, Thiry M, Sirri V, Lafontaine DLJ (2010) The nucleolus: structure/function relationship in RNA metabolism. Wires RNA 1:415-430

Highett MI, Beven AF, Shaw PJ (1993a) Localization of 5 S genes and transcripts in Pisum sativum nuclei. J Cell Sci 105:1151-1158

Highett MI, Rawlins DJ, Shaw PJ (1993b) Different patterns of rDNA distribution in Pisum sativum nucleoli correlate with different levels of nucleolar activity. J Cell Sci 104:843-852

Hozák P, Roussel P, Hernandez-Verdun D (1992) Procedures for specific detection of silver-stained nucleolar proteins on Western blots. J Histochem Cytochem 40:1089-1096

Huang S (2002) Building an efficient factory: where is pre-rRNA synthesized in the nucleolus? J Cell Biol 157:739-741

Hutten S, Prescott A, James J, Risenberg S, Boulon S, Lam YW, Lamond AI (2011) An intranucleolar body associated with rDNA. Chromosoma 120:481-499
Ide S, Miyazaki T, Maki H, Kobayashi T (2010) Abundance of ribosomal RNA gene copies maintains genome integrity. Science 327:693-696

Inagaki S, Kukutani T (2010) Control of genic DNA methylation in Arabidopsis. J Plant Res 123:299-302

Jacobson MR, Pederson T (1998) Localization of signal recognition particle RNA in the nucleolus of mammalian cells. Proc Natl Acad Sci U S A 95:7981-7986

Jarrous N, Wolenski JS, Wesolowski D, Lee C, Altman S (1999) Localization in the nucleolus and coiled bodies of protein subunits of the ribonucleoprotein ribonuclease P. J Cell Biol 146:559-571

Jordan EG (1984) Nucleolar nomenclature. J Cell Sci 67:217-220

Jordan EG, McGovern (1981) The quantitative relationship of the fibrillar centres and other nucleolar components to changes in growth conditions, serum deprivation and low doses of actinomycin $\mathrm{D}$ in cultured diploid human fibroblasts (strain MRC-5). J Cell Sci 52: 373-389

Jordan EG, Martini G, Bennett MD, Flavell RB (1982) Nucleolar fusion in wheat. J Plant Sci 56:485-495

Kalmárová M, Smirnov E, Mašata M, Koberna K, Ligasová A, Popov A, Raška I (2007) Positioning of NORs and NOR-bearing chromosomes in relation to nucleoli. J Struct Biol 160:49-56

Karni-Schmidt O, Zupnick A, Castillo M, Ahmed A, Matos T, Bouvet P, Cordon-Cardo C, Prives C (2008) p53 is localized to a sub-nucleolar compartment after proteasomal inhibition in an energy-dependent manner. J Cell Sci 121:4098-4105

Kim SH (2009) Plant nucleolar dynamics. J Plant Biol 52:193-201

Kim SH, Ryabov EV, Kalinina NO, Rakitina DV, Gillespie T, MacFarlane S, Haupt S, Brown JWS, Talinsky M (2007) Cajal bodies and the nucleolus are required for a plant virus systemic infection. EMBO J 26:2169-2179

Kim SH, Koraleva OA, Lewandowska D, Pendle AF, Clark GP, Simpson CG, Shaw PJ, Brown JWS (2009) Aberrant mRNA transcripts and the nonsense-mediated decay proteins UPF2 and UPF3 are enriched in the Arabidopsis nucleolus. Plant Cell 21:2045-2057

Kim SH, Spensley M, Choi SK, Calixto CPG, Pendle AF, Koraleva O, Shaw PJ, Brown JWS (2010) Plant U13 orthologues and orphan snoRNAs identified by RNomics of RNA from Arabidopsis nucleoli. Nucleic Acids Res 38:3054-3067

Kobayashi T (2008) A new role of the rDNA and nucleolus in the nucleus-rDNA instability maintains genome integrity. Bioessays 30:267-272

Koberna K, Malínsk J, Pliss A, Mašata M, Večeřová J, Fialová M, Bednár J, Raška I (2002) Ribosomal genes in focus: new transcripts label the dense fibrillar components and form clusters indicative of "Christmas trees" in situ. J Cell Biol 157:743-748

Koš M, Tollervey D (2010) Yeast pre-rRNA processing and modifications occur cotranscriptionally. Mol Cell 37:809-820

Krüger T, Scheer U (2010) p53 localizes to intranucleolar regions distinct from the ribosome production compartments. J Cell Sci 123:12031208

Lachner M, O’Sullivan RJ, Jenuwein T (2003) An epigenetic road map for histone lysine methylation. J Cell Sci 116:2117-2124

Lamaye F, Galliot S, Alibardi L, Lafontaine DLJ, Thity M (2011) Nucleolar structure across evolution: The transition between biand tricompartmentalized nucleoli lies within the class Reptilia. J Str Biol 174:352-359

Latonen L, Moore HM, Bai B, Jäämaa S, Laiho M (2011) Proteasome inhibitors induce nucleolar aggregation of proteasome target proteins and polyadenylated RNA by altering ubiquitin availability. Oncogene 30:790-805

Layat E, Sáez-Vásquez J, Tourmente S (2012) Regulation of pol Itranscribed $45 \mathrm{~S}$ rDNA and pol III-transcribed 5S rDNA in Arabidopsis. Plant Cell Physiol 53:267-276

Lazdins IB, Delannoy M, Sollner-Webb B (1997) Analysis of nucleolar transcription and processing domains and pre-rRNA movements by in situ hybridization. Chromosoma 105:481-495 
Léger-Silvestre I, Noaillac-Depeyre J, Faubladier M, Gas N (1997) Structural and functional analysis of the nucleolus of the fission yeast Schizosaccharomyces pombe. Eur J Cell Biol 72:13-23

Lempiäinen H, Shore D (2009) Growth control and ribosome biosynthesis. Curr Opin Cell Biol 21:855-863

Long EO, Dawid IB (1980) Repeated genes in eukaryotes. Annu Rev Biochem 49:727-764

Long H, He J, Sun H, Hao S, Jiao M (2008) In situ comparative studies on subnucleolar distribution and configuration of plant rDNA. Micron 39:405-410

Lorković ZJ, Barta A (2008) Role of Cajal bodies and nucleolus in the maturation of the U1 snRNP in Arabidopsis. PLoS ONE 3(12): e3989. doi:10.1371/journal.pone.0003989

Louvet E, Jonéra HR, Le Panse S, Hernandez-Verdun D (2005) Dynamics and compartmentation of the nucleolar processing machinery. Exp Cell Res 304:457-470

Louvet E, Jonéra HR, Berthuy I, Hernandez-Verdun D (2006) Compartmentation of the nucleolar processing proteins in the granular component is a CK2-driven process. Mol Biol Cell 17:25372546

Machyna M, Heyn P, Neugebauer KM (2013) Cajal bodies: where form meets functions. WIREs RNA 2013(4):17-34. doi:10.1002/wrna. 1139

Mais C, Wright JE, Prieto JL, Raggett SL, McStay B (2005) UBF-binding site arrays form pseudo-NORs and sequester the RNA polymerase I transcription machinery. Genes Dev 19:50-64

Mao YS, Zhang B, Spector DL (2011) Biogenesis and function of nuclear bodies. Trends Genet 27:295-306

Martin M, Medina FJ (1991) A Drosophila anti-RNA polymerase II antibody recognizes a plant nucleolar antigen, RNA polymerase I, which is mostly localized in fibrillar centres. J Cell Sci 100:99-107

Martin M, Moreno Diaz de la Espina S, Medina FJ (1989) Immunolocalization of DNA at nucleolar structural components in onion cells. Chromosoma 98:368-377

Martin M, García-Fernández LF, Moreno Díaz de la Espina S, NoaillacDepeyre J, Gas N, Medina FJ (1992) Identification and localization of nucleolin homologue in onion nucleoli. Exp Cell Res 199:74-84

Mayer C, Grummt I (2005) Cellular stress and nucleolar function. Cell Cycle 4:1036-1038

Mayer C, Schmitz KM, Li J, Grummt I, Santoro R (2006) Intergenic transcripts regulate the epigenetic state of rRNA genes. Mol Cell 22: 351-361

McKeown PC, Shaw PJ (2009) Chromatin: linking structure and function in the nucleolus. Chromosoma 118:11-23

McStay B (2006) Nucleolar dominance: a model for rRNA gene silencing. Genes Dev 20:1207-1214

McStay B, Grummt I (2008) The epigenetics of rRNA genes: from molecular to chromosome biology. Annu Rev Cell Dev Biol 24: $131-157$

Medina FJ, Risueño MC, Moreno Diaz de la Espina S (1983a) 3-D reconstruction and morphometry of the fibrillar centres in plant cells in relation to the nucleolar activity. Biol Cell 48:575-586

Medina FJ, Risueño MC, Sánchez-Pina MA, Fernández-Gómez ME (1983b) A study on nucleolar silver staining in plant cells. The role of argyrophilic proteins in nucleolar physiology. Chromosoma 88: $149-155$

Medina FJ, Solanilla EL, Sanchez-Pina MA, Fernandez-Gomez ME (1986) Cytological approach to the nucleolar functions detected by silver staining. Chromosoma 94:259-266

Medina FJ, Cerdido A, de Cárcer G (2000) The functional organization of the nucleolus in proliferating plant cells. Eur J Histochem 44:117131

Medina FJ, González-Camacho F, Manzano AI, Manrique A, Herranz R (2010) Nucleolin, a major conserved multifunctional nucleolar phosphoprotein of proliferating cells. J Appl Biomed 8:141-150
Mélèse T, Xue Z (1995) The nucleolus: an organelle formed by the act of building ribosome. Curr Opin Cell Biol 7:319-324

Mineur P, Jennane A, Thiry M, Deltour R, Goessens G (1998) Ultrastructural distribution of DNA within plant meristematic cell nucleoli during activation and the subsequent inactivation by a cold stress. J Struct Biol 123:199-210

Minguez A, Moreno Diaz de la Espina S (1996) In situ localization of nucleolin in the plant nucleolar matrix. Exp Cell Res 222:171-178

Moreno Díaz de la Espina S, Risueño SC, Fernández-Gómez ME, Tandler CJ (1976) Ultrastructural study of the nucleolar cycle in meristematic cells of Allium cepa. J Microsc Biol Cell 25:265-278

Moreno FJ, Rodrigo RM, Garcia-Herdugo G (1989a) An experimental approach to nucleolar organization in plant cells: a morphological, cytochemical and quantitative study. J Cell Sci 94:51-59

Moreno FJ, Rodrigo RM, Gracia-Navarro F, Garcia-Herdugo G (1989b) Nucleolar component behaviour in plant cells under different physiological conditions. A morphological, cytochemical and quantitative study. Biol Cell 65:65-74

Moreno FJ, Rodrigo RM, Garcia-Herdugo G (1990) Ag-NOR proteins and rDNA transcriptional activity in plant cells. J Histochem Cytochem 38:1879-1887

Moreno-Diaz de la Espina S, Medina FJ, Risueno MC (1980) Correlation of nucleolar activity and nucleolar vacuolation in plant cells. Eur J Cell Biol 22:724-729

Moss T, Stefanovsky VY (2002) At the center of eukaryotic life. Cell 109: $545-548$

Motte P, Deltour R, Mosen H, Bronchart R (1988a) Three-dimensional electron microscopy of the nucleolus and nucleolus-associated chromatin (NAC) during early germination of Zea mays L. Biol Cell 62: $65-81$

Motte P, Mosen H, Bronchart R, Deltour R (1988b) Ultrastructural localization of argyrophilic proteins in nucleoli of Zea mays by two silver staining techniques. Biol Cell 64:97-100

Motte PM, Loppes R, Menager M, Deltour R (1991) Three-dimensional electron microscopy of ribosomal chromatin in two higher plants: a cytochemical, immunocytochemical, and in situ hybridization approach. J Histochem Cytochem 39:1495-1506

Mougey EB, O'Reilly M, Osheim Y, Miller OL Jr, Beyer A, SollnerWebb B (1993) The terminal balls characteristic of eukaryotic rRNA transcription units in chromatin spreads are rRNA processing complexes. Genes Dev 7:1609-1619

Nazar RN (2004) Ribosomal RNA processing and ribosome biogenesis in eukaryotes. IUBMB Life 56:457-465

Názer E, Verdún RE, Sánchez DO (2012) Severe heat shock induces nucleolar accumulation of mRNAs in Trypanosoma cruzi. PLoS ONE 7(8):e43715. doi:10.1371/journal.pone. 0043715

Németh A, Längst G (2011) Genome organization in and around the nucleolus. Trends Genet 27:149-156

Németh A, Conesa A, Santoyo-Lopez J, Medina I, Montaner D, Péterfia B, Solovei I, Cremer T, Dopazo J, Längst G (2010) Initial genomics of the human nucleolus. PLoS Genet 6(3):e1000889. doi:10.1371/ journal.pgen.1000889

Newton K, Petfalski E, Tollervey D, Caceres JF (2003) Fibrillarin is essential for early development and required for accumulation of an intron-encoded small nucleolar RNA in the mouse. Mol Cell Biol 23:8519-8527

Nierras CR, Liebman SW, Warner JR (1997) Does Saccharomyces need an organized nucleolus? Chromosoma 105:444 451

Nougarede A, Landre P, Jennane A (1990) Intranucleolar visualization of nucleic acids and acidic proteins in inhibited and reactivated pea cotyledonary buds. Protoplasma 156:183-191

Ochs RL, Lischwe MA, Spohn WH, Busch H (1985) Fibrillarin: a new protein of the nucleolus identified by autoimmune sera. Biol Cell 54: $123-134$

Okuwaki M, Tsujimoto M, Nagata K (2002) The RNA binding activity of a ribosome biogenesis factor, nucleophosmin/B23, is modulated by 
phosphorylation with a cell cycle-dependent kinase and by association with its subtype. Mol Biol Cell 13:2016-2030

Olausson KH, Nistér M, Lindström MS (2012) p53-dependent and independent nucleolar stress responses. Cell 1:774-798

Olson MOJ (2004) Sensing cellular stress: another new function for the nucleolus? Sci STKE, pe10

Olson MOJ, Dundr M (2005) The moving parts of the nucleolus. Histochem Cell Biol 123:203-216

Olson MOJ, Dundr M, Szebeni A (2000) The nucleolus: an old factory with unexpected capabilities. Trends Cell Biol 10:189-196

Olson MO, Hingorani K, Szebeni A (2002) Conventional and nonconventional roles of the nucleolus. Int Rev Cytol 219:199-266

Paredes S, Maggert KA (2009) Ribosomal DNA contributes to global chromatin regulation. Proc Natl Acad Sci U S A 106:1782917834

Paredes S, Branco AT, Hartl DL, Maggert KA, Lemos B (2011) Ribosomal DNA deletions modulate genome-wide gene expression: " $r D N A$-sensitive" genes and natural variation. PLoS Genet 7(4): e1001376. doi:10.1371/journal.pgen.1001376

Pederson T (1998) The plurifunctional nucleolus. Nucleic Acids Res 26: $3871-3876$

Pederson T (2010) The nucleolus. Cold Spring Harb Lab Press. doi:10. 1101/cshperspect.a000638

Pendle AF, Clark GP, Boon R, Lewandowska D, Lam YW, Andersen J, Mann M, Lamond AI, Brown JWS, Shaw PJ (2005) Proteomic analysis of the Arabidopsis nucleolus suggests novel nucleolar functions. Mol Biol Cell 16:260-269

Philimonenko VV, Zhao J, Iben S, Dingová H, Kyselá K, Kahle M, Zengraf H, Hofmann WA, de Lanerolle P, Hozak P, Grummt I (2004) Nuclear actin and myosin I are required for RNA polymerase I transcription. Nat Cell Biol 6:1165-1172

Philimonenko VV, Janáček J, Harata M, Hozák P (2010) Transcriptiondependent rearrangements of actin and nuclear myosin $\mathrm{I}$ in the nucleolus. Histochem Cell Biol 134:243-249

Ploton D, Thiry M, Menager M, Lepoint A, Adnet JJ, Goessens G (1987) Behaviour of nucleolus during mitosis. A comparative ultrastructural study of various cancerous cells lines using the Ag-NOR staining procedure. Chromosoma 95:95-107

Politz JC, Yarovoi S, Kilroy SM, Gowda K, Zwieb C, Pederson T (2000) Signal recognition particle components in the nucleolus. Proc Natl Acad Sci U S A 97:55-60

Politz JC, Polena I, Trask I, Bazett-Jones DP, Pederson T (2005) A nonribosomal landscape in the nucleolus revealed by the stem cell protein nucleostemin. Mol Biol Cell 16:3401-3410

Politz JCR, Hogan EM, Pederson T (2009) MicroRNAs with a nucleolar location. RNA 15:1705-1715

Pontes O, Pikaard CS (2008) siRNA and miRNA processing: new functions for Cajal bodies. Curr Opin Genet Dev 18:197-203

Pontes O, Vitins A, Ream TS, Hong E, Pikaard CS, Costa-Nunes P (2013) Intersection of small RNA pathways in Arabidopsis thaliana sub-nuclear domains. PLoS ONE 8(6):e65652. doi:10.1371/journal. pone. 0065652

Pontvianne F, Matia I, Douet J, Tourmente S, Medina FJ, Echeverria M, Sáez-Vásquez J (2007) Characterization of AtNUC-L1 reveals a central role of nucleolin in nucleolus organization and silencing of AtNUC-L2ne in Arabidopsis. Mol Biol Cell 18:369-379

Pontvianne F, Abou-Ellail M, Douet J, Comella P, Matia I, Chandrasekhara C, DeBures A, Blevins T, Cooke R, Medina FJ, Tourmente S, Pikaard CS, Sáez-Vásquez J (2010) Nucleolin is required for DNA methylation state and the expression of rRNA gene variants in Arabidopsis thaliana. PLoS Genet 6(11):e1001225. doi:10.1371/Journal.pgen.1001225

Pontvianne F, Blevins T, Chandraskhara C, Freng W, Stroud H, Jacobsen SE, Michaels SD, Pikaard CS (2012) Histone methylotransferases regulating rRNA gene dose and dosage control in Arabidopsis. Genes Dev 26:945-957
Pontvianne F, Blevins T, Chandraskhara C, Mozgová I, Hassel C, Pontes OMF, Tucker S, Mokroš P, Muchová V, Fajkus J, Pikaard CS (2013) Subnuclear partitioning of rRNA genes between the nucleolus and nucleoplasm reflects alternative epiallelic states. Genes Dev 27: $1545-1550$

Preti M, O’Donohue MF, Montel-Lehry N, Bortolin-Cavaillé ML, Choesmel V, Gleizes PE (2013) Gradual processing of the ITS1 from the nucleolus to the cytoplasm during synthesis of the human 18S rRNA. Nucleic Acids Res 41:4709-4723

Preuss S, Pikaard CS (2007) rRNA gene silencing and nucleolar dominance: insights into a chromosome-scale epigenetic on/off switch. Biochim Biophys Acta 1769:383-392

Prieto JL, McStay B (2005) Nucleolar biogenesis: the first small step. Biochem Soc Trans 33:1441-1443

Prieto JL, McStay B (2008) Pseudo-NORs: a novel model for studying nucleoli. Biochim Biophys Acta 1783:2116-2123

Rakitina DV, Talinsky M, Brown JWS, Kalinina N (2011) Two RNAbinding sites in plant fibrillarin provide interactions with various RNA substrates. Nucleic Acids Res 39:8869-8880

Raška I (2003) Oldies but goldies: searching for Christmas trees within the nucleolar architecture. Trends Cell Biol 13:517-523

Raška I, Reimer G, Jarník M, Kostrouch Z, Raška K Jr (1989) Does the synthesis of ribosomal RNA takes places within nucleolar fibrillar centers or dense fibrillar component? Biol Cell 65:79-82

Raška I, Koberna K, Malínský J, Fidlerová H, Mašata M (2004) The nucleolus and transcription of ribosomal genes. Biol Cell 96:579 594

Raška I, Shaw PJ, Cmarko D (2006a) Structure and function of the nucleolus in the spot light. Curr Opin Cell Biol 18:325-334

Raška I, Shaw PJ, Cmarko D (2006b) New insights into nucleolar architecture and activity. Int Rev Cytol 255:177-235

Rawlins DJ, Shaw PJ (1990) Three-dimensional organization of ribosomal DNA in interphase nuclei of Pisum sativum by in situ hybridization and optical tomography. Chromosoma 99:143-151

Reeder RH (1992) Regulation of transcription by RNA polymerase I. Cold Spring Harbor Laboratory Press, Transcriptional Regulation

Richards EJ, Elgin SC (2002) Epigenetics codes for heterochromatin formation and silencing: rounding up the usual suspects. Cell 108: 489-500

Risueño MC, Medina FJ (1986) The nucleolar structure in plant cells. Revis Biol Cell 7:1-154

Risueño MC, Testillano PS (1994) Cytochemistry and immunocytochemistry of nucleolar chromatin in plants. Micron 25:331-360

Risueño MC, Medina FJ, Moreno Díaz de la Espina S (1982) Nucleolar fibrillar centres in plant meristematic cells: ultrastructure, cytochemistry and autoradiography. J Cell Sci 58:313-329

Rodrigo RM, Carmen Rendón M, Torreblanca J, García-Herdugo G, Moreno FJ (1992) Characterization and immunolocalization of RNA polymerase I transcription factor UBF with anti-NOR serum in protozoa, higher plant and vertebrate cells. J Cell Sci 103:10531063

Rudra D, Warner JR (2004) What better measure than ribosome synthesis? Genes Dev 18:2431-2436

Russell J, Zomerdijk JCBM (2005) RNA-polymerase-I-directed rDNA transcription, life and works. Trends Biochem Sci 30:86-96

Sáez-Vásquez J, Echeverría M (2006) Polymerase I transcription. In: Grasser KD (ed) Regulation of transcription in plants, Annual Plant Review, vol 29. Blackwell, Oxford, pp 162-183

Sáez-Vásquez J, Medina FJ (2008) The plant nucleolus. Adv Bot Res 47: $1-46$

Sáez-Vásquez J, Caparros-Ruiz D, Barneche F, Echeverria M (2004) A plant snoRNP complex containing snoRNAs, fibrillarin, and nucleolin-like proteins is competent for both rRNA gene binding and pre-rRNA processing in vitro. Mol Cell Biol 24:7284-7297

Sameshima M, Fujimoto H, Imai Y, Tsukita S, Hashimoto Y (1991) Relation of nucleolar structure and position to the cytoplasmic 
microtubule system inDictyostelium. Cell Motil Cytoskel 18:293303

Santoro R (2005) The silence of the ribosomal RNA genes. Cell Mol Life Sci 62:2067-2079

Santoro R, Grummt I (2005) Epigenetic mechanism of rRNA gene silencing: temporal order of NoRC-mediated histone modification, chromatin remodeling, and DNA methylation. Mol Cell Biol 25: 2539-2546

Sarshad A, Sadeghifar F, Louvet E, Mori R, Böhm S, Al-Muzzaini B, Vintermist A, Fomproix N, Östlund AK, Percipalle P (2013) Nuclear myosin 1c facilitates the chromatin modifications required to activate rRNA gene transcription and cell cycle progression. PLoS Genet 9(3):e1003397. doi:10.1371/journal.pgen.1003397

Sato S, Fujie T (1997) Architecture of the nucleolonema in root-tip cells of Raphanus sativus. Cytologia 62:411-419

Sato S, Myoraku A (1994) Three-dimensional organization of nucleolar DNA in the higher plant nucleolonema studied by immunoelectron microscopy. Micron 25:431-437

Sato S, Sato Y (2010) Localization of rDNA at nucleolar structural components by immunoelectron microscopy. Methods Mol Biol 657:287-296

Sato S, Yano H, Makimoto Y, Kaneta T, Sato Y (2005) Nucleolonema as a fundamental substructure of the nucleolus. J Plant Res 118:71-81

Savino TM, Gébrane-Younès J, De Mey J, Sibarita JB, HernandezVerdun D (2001) Nucleolar assembly of the rRNA processing machinery in living cells. J Cell Biol 53:1097-1110

Scheer U, Rose KM (1984) Localization of RNA polymerase I in interphase cells and mitotic chromosomes by light and electron microscopic immunocytochemistry. Proc Natl Acad Sci U S A 81:14311435

Schimmang T, Tollervey D, Kern H, Frank R, Hurt EC (1989) A yeast nucleolar protein related to mammalian fibrillarin is associated with small nucleolar RNA and id essential for viability. EMBO J 8:40154024

Schneider DA (2012) RNA polymerase I activity is regulated at multiple steps in the transcription cycle: recent insights into factors that influence transcription elongation. Gene 493:176-184

Schneider DA, Michel A, Sikes ML, Vu L, Dodd JA, Salgia S, Osheim YN, Beyer AL, Nomura M (2007) Transcription elongation by RNA polymerase I is linked to efficient rRNA processing and ribosome assembly. Mol Cell 26:217-229

Shang G, Wang F, Hao S, Jiao M (2009) Dynamic changes of nucleolar DNA configuration and distribution during the cell cycle in Allium sativum cells. Micron 40:449-454

Shaw PJ (2005) The Nucleolus. In: Encyclopedia of Life Sciences, Chichester: John Wiley \& Sons, Ltd. http://www.els.net.doi:10. 1038/npg.els.0003958

Shaw P, Brown J (2012) Nucleoli: composition, function, and dynamics. Plant Physiol 158:44-51

Shaw PJ, Jordan EG (1995) The nucleolus. Annu Rev Cell Dev Biol 11: 93-121

Shaw PJ, Highet MI, Beven AF, Jordan EG (1995) The nucleolar architecture of polymerase I transcription and processing. EMBO J 14: 2896-2906

Shaw PJ, Beven AF, Wells B, Highett MI, Jordan EG (1996) The organization of nucleolar activity in plants. J Microsc 181:178-185

Shaw PJ, Beven AF, Leader DJ, Brown JWS (1998) Localization and processing from a polycistronic precursor of novel snoRNAs in maize. J Cell Sci 111:2121-2128

Shaw PJ, Abranches R, Santos AP, Beven AF, Stoger E, Wegel E, Gonzalez-Melendi P (2002) The architecture of interphase chromosomes and nucleolar transcription sites in plants. J Str Biol 140:3138

Sirri V, Urcuqui-Inchima S, Roussel P, Hernandez-Verdun D (2008) Nucleolus: the fascinating nuclear body. Histochem Cell Biol 129: $13-31$
Sobol MA, Gonzalez-Comacho F, Redriguez-Vilarino V, Kordyum EL, Medina FJ (2005) Clinorotation influences rDNA and NopA100 localization in nucleoli. Adv Space Res 36:1254-1262

Sobol MA, González-Comacho F, Redriguez-Vilariño V, Kordyum EL, Medina FJ (2006) Subnucleolar location of fibrillarin and NopA64 in Lipidium sativum root meristematic cells is changed in altered gravity. Protoplasma 228:209-219

Spector DL (2001) Nuclear domains. J Cell Sci 114:2891-2893

Staněk D, Koberna K, Pliss A, Malínský J, Mašata M, Večeřová $J$, Risueño MC, Raška I (2001) Non-isotopic mapping of ribosomal RNA synthesis and processing in the nucleolus. Chromosoma 110: 460-470

Stepiński D (2004) Ultrastructural and autoradiographic studies of the role of nucleolar vacuoles in soybean root meristem. Folia Histochem Cytobiol 42:57-61

Stępiński D (2008) Nucleolar vacuolation in soybean root meristematic cell during recovery after chilling. Biol Plant 52:507-512

Stepiński D (2009) Immunodetection of nucleolar proteins and ultrastructure of nucleoli of soybean root meristematic cells treated with chilling stress and after recovery. Protoplasma 235:77-89

Stępiński D (2010) Organization of the nucleoli of soybean root meristematic cells at different states of their activity. Micron 41:283-288

Stępiński D (2012a) Immunofluorescent localization of ubiquitin and proteasomes in nucleolar vacuoles of soybean root meristematic cells. Eur J Histochem 56:71-77

Stępiński D (2012b) Levels of DNA methylation and histone methylation and acetylation change in root tip cells of soybean seedlings grown at different temperatures. Plant Physiol Biochem 61:9-17

Stępiński D (2013) Nucleolar chromatin organization at different activities of soybean root meristematic cell nucleoli. Protoplasma 250: $723-730$

Stępiński D, Kwiatkowska M (2003) Autoradiographic and ultrastructural studies of the influence of chilling on soybean root meristem nucleoli. Acta Biol Cracov Ser Bot 45:35-42

Strohner R, Németh A, Nightingale KP, Grummt I, Becker PB, Längst G (2004) Recruitment of the nucleolar remodeling complex NoRC establishes ribosomal DNA silencing in chromatin. Mol Cell Biol 24:1791-1798

Strunk BS, Karbstein K (2009) Powering through ribosome assembly. RNA 15:2083-2104

Suzuki A, Kogo R, Kawahara K, Sasaki M, Nishio M, Maehama T, Sasaki T, Mimori K, Mori M (2012) A new PICTure of nucleolar stress. Cancer Res 103:632-637

Taliansky ME, Brown JWS, Rajamaki ML, Valkonen JPT, Kalinina NO (2011) Involvement of the plant nucleolus in virus and viroid infections: parallels with animal pathosystems. In: Maramorosch K, Shatkin AJ, Murphy FA (eds) Advances in Virus Research. Elsevier Inc, pp 119-158

Tao W, Xu W, Valdivia MM, Hao S, Zhai ZH (2001) Distribution and transcription activity of nucleolar DNA in higher plant cells. Cell Biol Int 25:1167-1171

Testillano PS, Sanchez-Pina MA, Olmedilla A, Ollacarizqueta MA, Tandler CJ, Risueno MC (1991) A specific ultrastructural method to reveal DNA: the NAMA-Ur. J Histochem Cytochem 39:1427-1438

Thiry M, Lafontaine DLJ (2005) Birth of a nucleolus: the evolution of nucleolar compartments. Trends Cell Biol 15:194-199

Thiry M, Thiry-Blaise L (1989) In situ hybridization at the electron microscope level: an improved method for precise localization of ribosomal DNA and RNA. Eur J Cell Biol 50:235-243

Thiry M, Scheer U, Goessens G (1991) Localization of nucleolar chromatin by immunocytochemistry and in situ hybridization at the electron microscopic level. Electron Microsc Rev 4:85-110

Thiry M, Ploton D, Menager M, Goessens G (1993) Ultrastructural distribution of DNA within the nucleolus of various animal cell lines or tissues revealed by terminal deoxynucleoltidyl transferase. Cell Tissue Res 271:33-45 
Thiry M, Lamaye F, Lafontaine DLJ (2011) The nucleolus: when two became three. Nucleus 2:289-293

Thompson WF, Beven AF, Wells B, Shaw PJ (1997) Sites of rDNA transcription are widely dispersed through the nucleolus in Pisum sativum and can comprise single genes. Plant J 12:571-581

Trendelenburg MF, Zatsepina OV, Waschek T, Schlegel W, Tröster H, Rudolph D, Schmahl G, Spring H (1996) Multiparameter microscopic analysis of nucleolar structure and ribosomal gene transcription. Histochem Cell Biol 106:167-192

Tsai RY, McKay RD (2002) A nucleolar mechanism controlling cell proliferation in stem cells and cancer cells. Genes Dev 16:2991-3003

Tucker S, Vitins A, Pikaard CS (2010) Nucleolar dominance and ribosomal RNA gene silencing. Curr Opin Cell Biol 22:351-356

Visa N (2005) Actin in transcription. EMBO Rep 6:218-219

Visintin R, Amon A (2000) The nucleolus: the magician's hat for cell cycle tricks. Curr Opin Cell Biol 12:372-377

Visintin R, Hwang ES, Amon A (1999) Cfi 1 prevents premature exit from mitosis by anchoring Cdc 14 phosphatase in the nucleolus. Nature 398:818-823

Wachtler F, Mosgöller W, Schwarzacher HG (1990) Electron microscopic in situ hybridization and autoradiography: localization and transcription of rDNA in human lymphocyte nucleoli. Exp Cell Res 187: 346-348

Wang L, Ren X, Xing J, Zheng AC (2010) The nucleolus and viral infections. Virol Sin 25:151-157
Warner JR (1999) The economics of ribosome biosynthesis in yeast. Trends Biochem Sci 24:437-440

Wei T, Baiqu H, Chunxiang L, Zhonghe (2003) In situ visualization of rDNA arrangement and its relationship with subnucleolar structural regions in Allium sativum cell nucleolus. J Cell Sci 116:1117-1125

Williams LM, Charest PM, Lafontaine JG (1985) Nuclease-gold and protease-gold labelling over the nucleolar vacuoles of pea root tip cells. Biol Cell 55:21-26

Yano H, Sato S (2000) Ultrastructural localization of transcription sites, DNA, and RNA reveals a concentric arrangement of structural and functional domains in plant nucleolonema. Protoplasma 214:129140

Yano H, Sato S (2002) Combination of electron microscopic in situ hybridization and anti-DNA antibody labeling reveals a peculiar arrangement of ribosomal DNA in the fibrillar centers of the plant cell nucleolus. J Electron Microsc 51:231-239

Yuan X, Zhao J, Zentgraf H, Hoffmann-Rohrer U, Grummt I (2002) Multiple interactions between RNA polymerase I, TIF-IA and $\mathrm{TAF}_{\mathrm{I}}$ subunits regulate preinitiation complex assembly at the ribosomal gene promoter. EMBO Rep 3:1082-1087

Zougman A, Mann M, Wiśniewski JR (2011) Identification and characterization of a novel ubiquitous nucleolar protein 'NARR' encoded by a gene overlapping the rab34 oncogene. Nucleic Acids Res 39: 7103-7113 